\title{
Cellular and molecular pathology of gastric carcinoma and precursor lesions: A critical review
}

\author{
Si-Chun Ming \\ Department of Pathology and Laboratory Medicine, Temple University School of Medicine, 3400 North Broad Street, Philadelphia, \\ Pennsylvania 19140, USA
}

\begin{abstract}
:
The cellular and molecular pathology of gastric cancer and its precursors are reviewed and discussed. Gastric carcinogenesis is a multistep phenomenon, beginning with precancerous conditions. Among these, adenoma is a direct precursor, because of the dysplastic nature of its cells. However, gastric adenoma is relatively rare. Chronic atrophic gastritis (CAG) is the most common precancerous condition, in which intestinal metaplasia often occurs. Carcinoma develops in CAG through stages of hyperplasia and dysplasia involving both metaplastic and non-metaplastic glands. Molecular alterations, including replication error and $p 53$ and $A P C$ gene mutation and aneuploidy have been found in some of these conditions, confirming their role in carcinogenesis. Carcinomas of the stomach are heterogeneous in cellular composition. Both intestinal and gastric types of cells are found in all types of tumors, indicating the unique characteristics of gastric cancer. Many molecular lesions have been found in gastric carcinomas. Basic changes involve replication errors, telomerase activity, and aberrant CD44 transcripts. Many other changes often show differences in the frequency of their occurrence between the two major histological types of gastric carcinoma: well differentiated versus poorly differentiated, or intestinal type versus diffuse type. The timing and frequency of these changes in the stomach differ from the timing and frequency in colonic carcinogeneis. Pathological evaluation remains reliable and meaningful, in basic research as well as clinical management. To obtain correlation with molecular alterations, the need for detailed pathologic classification of gastric carcinoma is recognized, taking into account its biologic behavior and grades of cell differentiation.

The cellular and molecular pathology of gastric cancer and its precursors are reviewed and discussed. Gastric carcinomas are unique in their heterogeneity in both cellular composition and molecular changes.
\end{abstract}

Offprint requests to: S.-C. Ming

Received for publication on Jun. 3, 1998; accepted on Jul. 27, 1998
Key words: stomach carcinoma, pathology, genetics

\section{Introduction}

Gastric cancer is one of the leading causes of cancer death throughout the world, although its incidence has declined in many countries. The cause of the decline has not been elucidated. The influence of environmental factors, including changes in life-style and eating habits, remains significant.

The etiology of gastric cancer is still unclear. The possibilities have expanded to include infectious agents, notably Helicobacter pylori. The remarkable advances in molecular technology seen in recent years have enhanced our understanding of the mechanisms of carcinogenesis, although the impact of molecular technology on clinical management is still limited. In many ways, pathological investigation remains a major tool in the study of gastric cancer. Recent developments in pathology and molecular technology are discussed in this review. Etiologic considerations and precancerous changes are briefly presented, with regard to their relationship with the pathologic features of gastric carcinoma, and in terms of their relationship to the histological types of gastric cancer.

\section{Epidemiology of gastric carcinoma}

The mortality rate of gastric carcinoma shows wide geographic variation. Epidemiologic studies comparing high-risk with low-risk regions give some insight into the possible etiological factors in gastric carcinoma. Additional information has been obtained by timetrend studies, which show a steady decline in the mortality rate in most countries [1]. The United States has shown a remarkable decline in gastric cancer since 1930 
[2]. From 1950 to 1992, the incidence decreased by $75 \%$ and the mortality rate by $78 \%$ [3]. The decrease has been less significant in recent years and the survival rate has remained low. The 5-year survival rate for patients with gastric cancer was only $19 \%$ during the period 1986 to 1991.

\section{Etiologic factors}

The etiology of gastric carcinoma has not been clearly delineated. Genetic influence appears to be minor. The most important factors are environmental, as shown by migrant studies. When people migrated from a high-risk to a low-risk region, the incidence of gastric carcinoma decreased, with the decrease being more pronounced in the second than in the first generation [4], suggesting the lasting effect of carcinogenic exposure in early life.

Diet appears to be the most important of the environmental factors. Improved diet has been credited for the decline in gastric cancer mortality [5]. A highcalorie diet, red meat, and salty foods are risk factors, whereas fresh fruits, fiber, beta-carotene, and vitamins are protective, particularly for intestinal type cancer $[6,7]$. Protective factors for diffuse type cancer are carbohydrate and vitamin C [7].

The carcinogens responsible for human gastric cancer are suspected to be N-nitroso compounds, which may be endogenous. The low acidity of gastric juice in chronic gastritis, which often precedes carcinoma, allows the overgrowth of bacteria which may promote invivo $\mathrm{N}$-nitroso formation [8], while vitamins $\mathrm{C}$ and $\mathrm{E}$ may block this process [1].

In recent years, Helicobacter pylori has been found to be associated with gastric cancer [9]. It was suggested that prolonged infection since childhood may account for the high incidence of gastric cancer in high-risk countries [9]. However, the vast majority of people with $H$. pylori gastritis do not develop gastric cancer. Furthermore, the odds ratios for gastric cancer in H. pyloriinfected individuals do not differ widely between high- and low-risk countries [10]. The infection appears to affect older persons, and there is a general decline in the infection rate [11]. These changes may explain the decreasing incidence of gastric cancer, particularly the intestinal type [9].

The mechanism of $H$. pylori-associated carcinogenesis has been related to the organism's ability to cause gastritis with prominent inflammatory cells and increased cell proliferation. Persistent injury eventually results in mucosal atrophy and intestinal metaplasia, a precancerous condition for intestinal type gastric carcinoma. The diffuse type carcinoma is not associated with intestinal metaplasia, but appears to arise from hyperplastic neck cells, although $H$. pylori was found in
$100 \%$ of stomachs with diffuse carcinoma and in $78 \%$ of those with intestinal type carcinoma [12].

In support of the relation of $H$. pylori to gastric cancer, antibodies from patients with both gastric carcinoma and $H$. pylori gastritis were shown to cross-react with extracts of both $H$. pylori and carcinoma cells, and enhanced the growth of tumor cells in vitro [13]. About $60 \%$ of $H$. pylori possess the cagA gene. cagA-positive $H$. pylori causes more severe gastritis and a higher risk of developing gastric carcinoma than cagA-negative $H$. pylori [14]. A study in China, however, did not reveal a relationship between cagA protein and gastric cancer [15]. The reported higher $H$. pylori positivity in association with intestinal type gastric carcinoma than with diffuse type carcinoma [16] was not confirmed by others $[17,18]$. Eradication of $H$. pylori reduced the severity of atrophic gastritis and the proliferative activity of the epithelium, and inhibited intestinal metaplasia [19], but did not reverse dysplastic epithelium [20].

The long latency period between the initial H. pylori infection and the development of gastric cancer implies the cumulative effects of many factors. Prolonged $H$. pylori infection, resulting in an altered microenvironment in the stomach, together with other risk factors, allows colonization of other bacteria, particularly the anaerobes, and in-vivo production of procarcinogens in the stomach. In addition, $H$. pylori blocks gastric secretion of ascorbic acid, allowing the carcinogens to exert their damaging effect on the gastric epithelium [10]. It appears that in the late stage of carcinogenesis $H$. pylori per se is no longer essential. In fact, $H$. pylori does not inhabit the metaplastic mucosa, except for glands showing only incomplete metaplasia [21].

Epstein-Barr virus (EBV) is another infectious agent involved in the development of gastric carcinoma. The carcinoma is usually poorly differentiated with prominent lymphoid stroma, so-called lymphoepithelioma-like carcinoma. With in-situ hybridization and polymerase chain reaction techniques, EBV was detected in over $80 \%$ of carcinomas with lymphoid stroma and in $6 \%-9 \%$ of adenocarcinomas without lymphoid stroma [22].

\section{Precursors of gastric cancer}

Gastric carcinoma occurs with increased frequency in a number of gastric diseases [23], including chronic atrophic gastritis [24], peptic ulcer, in the gastric remnant after partial gastrectomy [25], adenoma, polyps [26], intestinal metaplasia, and hyperplastic gastropathy [27]. The precancerous potential of these conditions is recognized primarily by their clinical association with gastric cancer. The incidence of various precancerous conditions in early gastric carcinoma at the National Cancer 
Table 1. Precursors of gastric carcinoma (\%)

\begin{tabular}{lcc}
\hline Precursor & $\begin{array}{c}\text { Incidence of carcinoma } \\
\text { in patients with } \\
\text { precursor lesion }(\%)\end{array}$ & $\begin{array}{c}\text { Incidence of precursor } \\
\text { lesion in patients with } \\
\text { early carcinoma }\end{array}$ \\
\hline Chronic atrophic gastritis & $0-13^{24}$ & 94.8 \\
Pernicious anemia & $0.5-12.3^{24}$ & 1.4 \\
Verrucous gastritis & $1-2^{24}$ & 0.7 \\
Chronic gastric ulcer & $0.4-7.8^{25}$ & 0.1 \\
Gastric stump & $1-2^{26}$ & 0.5 \\
Hyperplastic polyp & $6-21^{26}$ & 2.5 \\
Flat adenoma & $20-75^{26}$ & \\
Papillovillous adenoma & $5-10^{27}$ & \\
Ménétrier's disease & & \\
\hline
\end{tabular}

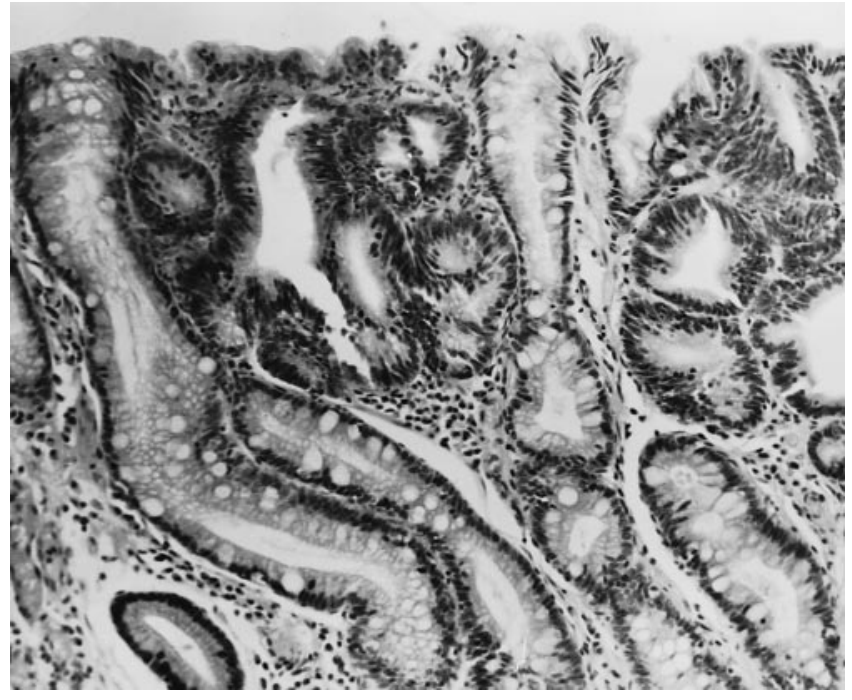

Fig. 1. Tubular flat adenoma showing crowded and elongated but uniform nuclei of the adenomatous glands. The adjacent glands show incomplete intestinal metaplasia, with goblet cells scattered among columnar mucous cells of the stomach. Hematoxylin and eosin stain. $\times 150$

Center in Tokyo, Japan [23] is shown in Table 1. The gross and microscopic pathologic features of gastric carcinoma may be related to their respective precancerous lesions, particularly in their early stage.

\section{Epithelial polyps}

Epithelial polyps are classified into neoplastic and nonneoplastic types. Non-neoplastic polyps are further classified as hyperplastic, hamartomatous, heterotopic, and inflammatory. Inflammatory polyps have no malignant potential. The hyperplastic polyp is a regenerative lesion, and malignant change occurs in only $2 \%$ or less [26]. Carcinoma develops very rarely in the hamartomatous polyp or heterotopic pancreatic tissue.

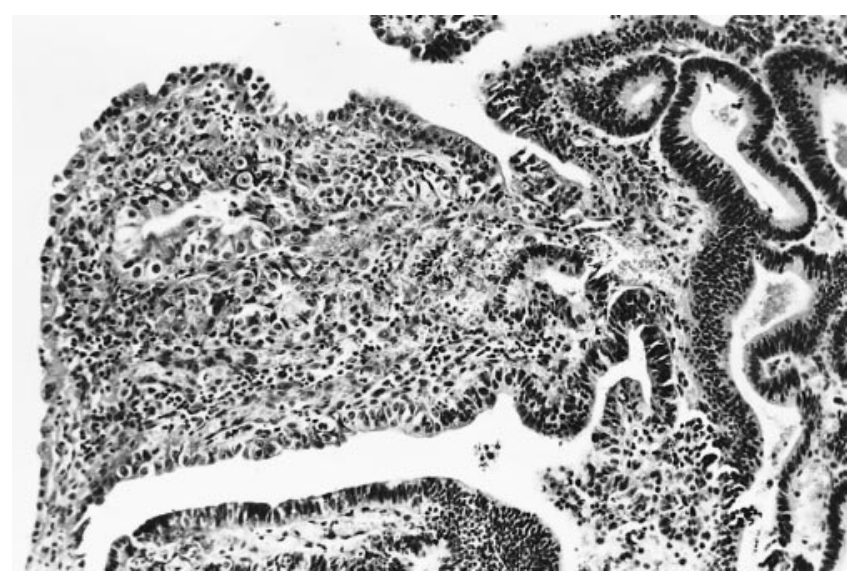

Fig. 2. Papillary adenoma. The nuclei are dense and cytoplasm is markedly reduced. Note focus of carcinoma on the left side. Hematoxylin and eosin stain. $\times 120$

The hamartomatous fundic gland polyp of the stomach seen in patients with familial adenomatous polyposis of colon has been found to have mutation of the adenomatous polyposis coli $(A P C)$ gene in $27 \%$ of patients, but no mutation of the p53 or K-ras gene [28]. However, fundic gland polyps are not precancerous. $p 53$ overexpression was not seen in hyperplastic polyps [29].

Neoplastic epithelial polyps are adenomas; these are divided into two gross types: flat and papillary. They usually occur in the metaplastic mucosa. Histologically, flat adenomas (Fig. 1) are composed of tubular structures lined with mildly to moderately dysplastic epithelial cells. Papillary adenomas (Fig. 2) consist of tubulovillous glands lined with moderately to severely dysplastic cells. It is interesting to note the geographic distribution of these two types. The flat adenomas are seen mainly in Japan and the papillary adenomas mostly in Western countries. Carcinoma develops in about $6 \%-21 \%$ of flat adenomas and in $20 \%-76 \%$ of papillary adenomas [26] (Fig. 2). The frequency of carcinoma correlates with the severity of dysplasia. 
Table 2. Genetic alterations in precursors of gastric carcinomas (\%)

\begin{tabular}{|c|c|c|c|c|c|c|c|c|}
\hline \multirow[b]{2}{*}{ Gene } & \multirow[b]{2}{*}{ Alteration } & \multirow[b]{2}{*}{ CAG } & \multirow[b]{2}{*}{ Metapl } & \multicolumn{3}{|c|}{ Dysplasia } & \multirow[b]{2}{*}{ Adenoma } & \multirow[b]{2}{*}{ Reference no. } \\
\hline & & & & Uns & LG & $\mathrm{HG}$ & & \\
\hline$M I$ & RER+ & & 33 & & & & 42 & 30 \\
\hline$M I$ & RER+ & & 26 & & & & & 31 \\
\hline \multirow[t]{2}{*}{$M I$} & RER+ & & & & & & 8 & 32 \\
\hline & $\mathrm{LOH}$ & & & & & & 14 & \\
\hline p53 & Expression & 0 & 0 & 60 & & & & 33 \\
\hline$p 53$ & Mutation & 25 & 50 & 67 & & & & 33 \\
\hline p53 & Expression & 4 & 0 & & & & 0 & 29 \\
\hline p53 & Expression & & & & & 15 & 8 & 34 \\
\hline p53 & Mutation & & & & & & 30 & 35 \\
\hline p53 & Mutation & & & & & & 0 & 36 \\
\hline$A P C$ & Mutation & & & & & & 40 & 37 \\
\hline$A P C$ & Mutation & & & & & & 20 & 36 \\
\hline$A P C / M C C$ & $5 q \mathrm{LOH}$ & & 25 & 33 & & & & 38 \\
\hline$D C C$ & LOH & & & & & & 14 & 36 \\
\hline $\mathrm{K}$-ras & Mutation & & 0 & & & & 11 & 39 \\
\hline K-ras & Mutation & & 0 & & & & & 36 \\
\hline Telomerase & & & 35 & & & & & 40 \\
\hline Aneuploidy & & 0 & & 0 & 0 & 71 & & 41 \\
\hline Aneuploidy & & 18 & 22 & 33 & & & & 42 \\
\hline
\end{tabular}

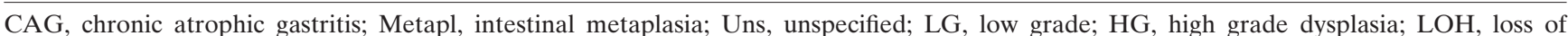
heterozygosity; RER, Replication error

Results of recent molecular studies of gastric adenoma are shown in Table 2. Alterations have been found, in addition to microsatellite instability [30-32], in the p53 [29,33-36] APC [36,37] APC/mutated in colorectal cancer (MCC) [38] and deleted in colorectal cancer $(D C C)$ [36] genes. There is no mutation of the $\mathrm{K}$ ras oncogene [36,39]. The results of molecular studies are sometimes inconsistent. Semba et al. [30] found microsatellite instability in $42 \%$ of adenomas, while Tamura et al. [32]. found microsatellite instability in only $8 \%$. Similar variations in results were reported for p53 and APC mutation. Tamura et al. [43] discovered loss of heterozygosity at many gene loci, including $A P C$ and $p 53$, in over $33 \%$ of differentiated carcinomas, but in less than $10 \%$ of adenomas. These findings have raised opposing views regarding the importance of the adenoma-carcinoma sequence in the stomach. Compared with the high frequency of these changes in colonic adenomas [44], those investigators who found lower rates in the stomach considered the adenomacarcinoma sequence in the stomach a rare occurrence, while those showing higher frequency of changes upheld the adenoma-carcinoma sequence as important in gastric carcinogenesis.

These disputes may be explained if one considers the following facts: (1) Adenoma is common in the colon, but infrequent in the stomach. Adenoma is the main precancerous lesion in the colon and a minor one in the stomach. (2) The pathologic features of adenomas in these two organs are distinctly different. Colonic adenomas are mostly papillary, irrespective of geographic location and have a high rate of malignant change. The pathology of gastric adenomas in Western countries is similar to that of colonic adenomas. In Japan, where most molecular studies are performed, gastric adenomas are mostly flat tubular lesions with low-grade dysplasia and a slow growth rate. Such lesions are rare in other countries. (3) The background tissues surrounding carcinoma in the stomach and colon are also very different. Common sporadic colonic carcinomas and adenomas occur in histologically normalappearing mucosa, whereas gastric carcinomas and adenomas usually develop in an abnormal mucosa with prominent chronic gastritis and intestinal metaplasia. (4) Experimental animal models suggest differing roles of carcinogens and tissue factors in the stomach and colon. Gastric adenocarcinomas in rodents are usually induced by directly acting carcinogens, such as $\mathrm{N}$-methyl- $\mathrm{N}^{\prime}$-nitro-N-nitrosoguanidine (MNNG) [45]. Nitroso-compounds have also been suspected carcinogens for human gastric cancer [8]. Colonic carcinomas have been induced in rodents by procarcinogens requiring metabolic activation in the liver and by intestinal flora, such as dimethylhydrazine (DMH), as well as MNNG [44]. MNNG causes gastric erosion, intestinal metaplasia, and adenocarcinoma, but not adenoma [45]. In the colon, both MNNG- and DMH-treated mice developed carcinomas and adenomas with a high rate of 
malignant change [46]. However, in the MNNG-treated mice, epithelial dysplasia was seen in $39 \%$ and infiltrative carcinoma in $56 \%$. In the DMH-treated animals, these lesions were seen in only $7 \%$ and $17 \%$, respectively. These different results may be related to the nature of the carcinogens as well as to organ-specific responses. These various factors may explain the differing molecular findings for gastric and colonic adenomas. Therefore, it is necessary to analyze the molecular data according to the pathologic features of the adenomas in order to unravel the adenoma-carcinoma sequence in the stomach.

\section{Chronic atrophic gastritis (CAG)}

Chronic atrophic gastritis is common, with a reported incidence of $22 \%-37 \%$ in asymptomatic patients in Europe, increasing with age [46]. It is the most important precursor of gastric carcinoma, and is associated with $94.8 \%$ of early gastric carcinomas in Japan (Table 1 ). The incidence of gastric carcinoma in patients with CAG was $0 \%-13 \%$. [24] After follow-up of more than 11 years, this incidence was $7 \%-13 \%$ [47]. CAG is seen mainly in the elderly population. In high-risk areas for gastric cancer, however, it is common in young people as well. In CAG, there is increased proliferative activity in the mucosal epithelium, resulting in the presence of relatively immature cells in the glands [48]. p53 expression and aneuploidy have been noted occasionally [29,42] (Table 2).

CAG is often the result of $H$. pylori gastritis. In some patients, including postgastrectomy patients, the chronic gastritis is related to the influx of duodenal contents into the stomach. In a small proportion of patients, CAG is associated with immunologic fundic gastritis in pernicious anemia.

\section{Intestinal metaplasia (IM)}

The atrophic gastric mucosa often shows IM, but the extent of metaplasia varies. IM is a histologic, not a clinical entity. Based on the cell types and their functional structures, IM is classified as complete (type I) (Fig. 3) and incomplete (types II and III) (Fig. 1), as well as small intestinal and colonic subtypes [49]. The major differences among the subtypes are summarized in Table 3. In complete metaplasia, the gastric mucosa assumes the appearance of small intestinal (type IA in Table 3) (Fig. 3) or colonic (IB in Table 3) mucosa. In incomplete metaplasia, the columnar cells between the goblet cells resemble the mucous cells of the gastric foveolae (Fig. 1), but the mucus may consist of neutral mucoproteins (IIA gastric type in Table 3), sialomucin (IIB small intestinal type in Table 3), or sulfomucin (III colonic type in Table 3). The goblet cells contain

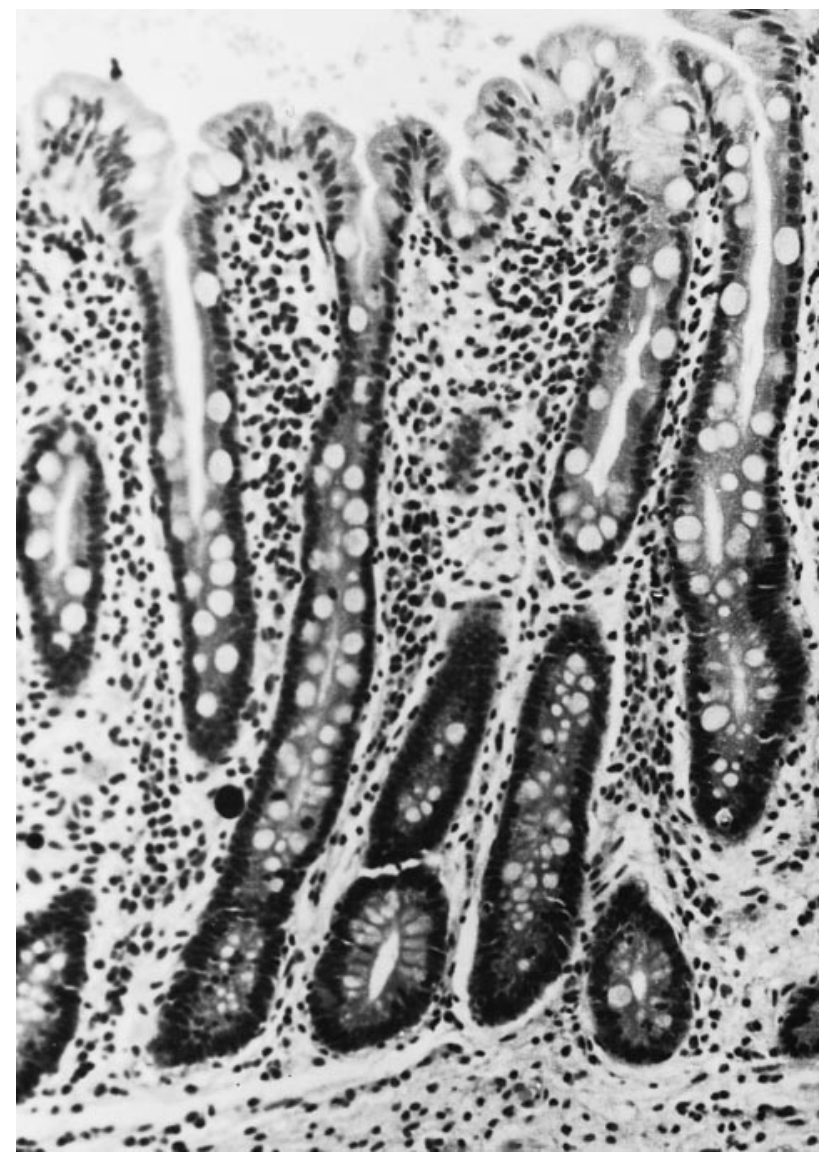

Fig. 3. Complete intestinal metaplasia, small intestinal type. The surface and foveolar mucous cells are replaced by goblet cells and absorptive cells. The regenerating zone of the glands is shifted to the bottom of glands where the nuclei are densely arranged, as in the small intestine. Hematoxylin and eosin stain. $\times 120$

sialomucin, sulfomucin, or both. Jass and Filipe [50] also divided intestinal metaplasia into complete (type I) and incomplete types. The incomplete type was further divided into two subtypes according to the type of mucin: non-sulfated mucin in type II and sulfated mucin in type III. Thus, type II incomplete metaplasia includes both gastric (IIA) and small intestinal (IIB) types, and type III corresponds to the colonic type. It should be noted that metaplastic glands are composed of heterogenous cell types although one type may dominate, and that gastric type mucous cells are often present also.

The precancerous nature of intestinal metaplasia is indicated by the frequent coexistence of intestinal metaplasia, particularly type III, with gastric carcinoma, mainly the glandular type (Fig. 4). The risk of gastric cancer is proportional to the extent of metaplasia [49]. However, follow-up studies of type III metaplasia did not show an increased risk of gastric carcinoma [51]. Examination of microcarcinomas less than $5 \mathrm{~mm}$ in diameter revealed that prominent metaplasia accompa- 
Table 3. Major differences among subtypes of intestinal metaplasia

\begin{tabular}{|c|c|c|c|c|c|}
\hline \multirow[b]{2}{*}{ Feature } & \multicolumn{2}{|c|}{ Complete type (I) } & \multicolumn{3}{|c|}{ Incomplete type (II, III) } \\
\hline & $\begin{array}{l}\text { Small-intestinal } \\
\text { (IA) }\end{array}$ & $\begin{array}{l}\text { Colonic } \\
\text { (IB) }\end{array}$ & $\begin{array}{l}\text { Gastric } \\
\text { (IIA) }\end{array}$ & $\begin{array}{l}\text { Small-intestinal } \\
\text { (IIB) }\end{array}$ & $\begin{array}{l}\text { Colonic } \\
\text { (III) }\end{array}$ \\
\hline Goblet cells & + & + & + & + & + \\
\hline Mucin type & Sialomucin & Sulfomucin & Sialomucin & Sialomucin & Either type \\
\hline Mucous columnar cells & - & - & + & + & + \\
\hline Mucin type & - & - & Neutral & Sialomucin & Sulfomucin \\
\hline Absorptive cells & + & + & - & - & - \\
\hline Striated borders & + & $+1-$ & - & $+/-$ & - \\
\hline Microvillar enzymes & + & $+1-$ & - & - & - \\
\hline Paneth cells & + & - & - & - & - \\
\hline
\end{tabular}

+ , Present; -, absent; neutral, neutral glycoprotein

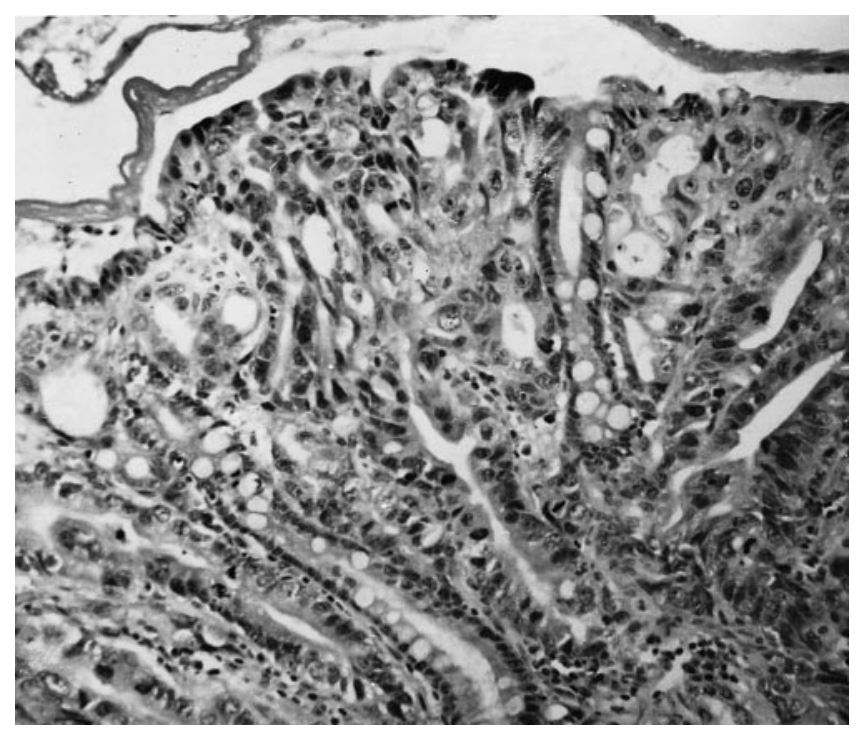

Fig. 4. Early intramucosal adenocarcinoma with stromal invasion in an area of intestinal metaplasia. Hematoxylin and eosin stain. $\times 180$

nied tubular carcinoma but not mucocellular (signet-ring cell) carcinoma [52]. In experimental animals, intestinal metaplasia is not a pre-requirsite precancerous lesion [53]. Thus, intestinal metaplasia may also be a paracancerous lesion. Complete metaplasia has been associated with lymphoepithelioma-like solid carcinoma [54]. However, small intestinal type complete metaplasia is common and its precancerous potential is uncertain.

Molecular studies of metaplastic tissue (Table 2) have shown varying degrees of alteration involving mismatch repair genes [30,31], p53 [29,33], and APC/MCC [38] genes. K-ras mutation was not observed [36,39]. Telomerase activity was present in $35 \%$ of the cases [40]. DNA aneuploidy was found in $22 \%$ of the cases [42]. In one report, microsatellite instability was noted in incomplete metaplasia [30]. The types of metaplasia were not stated in the other reports.

\section{Chronic gastric ulcer}

Chronic gastric ulcers had been considered a frequent cause of gastric cancer in the older literature. Recently, however, the importance of chronic ulcer as a precancerous lesion has been downgraded. At the National Cancer Center in Tokyo, chronic ulcer was considered a precursor in only $0.68 \%$ of early gastric cancers (Table 1). In follow-up studies, the incidence of carcinoma was zero in 5 years [55] and $2.2 \%$ in patients followed for 9 or more years [56]. The decreased incidence of ulcer-cancer may be the result of improved treatment for ulcer. More importantly, the malignant ulcer is often misdiagnosed as benign. Pathologically, ulcer-associated carcinomas are often infiltrative.

\section{Gastric remnants}

The reported incidence of carcinoma in the gastric remnant varied from 0 to $7.8 \%$, mostly being about $2 \%$ [25]. The variation is related in part to the time factor. Carcinoma usually develops more than 10 years after the initial gastrectomy. The type of gastrectomy procedure and the nature of the preoperative disease are not significant factors. Compared to ordinary carcinoma of the stomach, the development of stump carcinoma showed no difference in relation to sex, metaplasia, dysplasia, gross morphology, or histologic type [57].

The gastric remnant often shows gastritis, cystic glands, intestinal metaplasia, and dysplasia [25]. The severity of mucosal changes in the stomach stump correlates with the gastric $\mathrm{pH}$ [58]. Polyps may also occur, mainly of the hyperplastic type. The degree of dysplasia is generally mild and may regress. Severe dysplasia plays an important role in carcinogenesis. The types of carcinoma are about equally divided between the intestinal and diffuse types. Experimentally, gastrojejunostomy increases the incidence of chemically induced cancer in the rat stomach [59]. p53 mutation was 
detected in $36 \%$ of stump carcinomas and in $80 \%$ of its adjacent mucosa, higher than the $29 \%$ in ordinary gastric carcinoma and the $25 \%$ in adjacent mucosa [57].

\section{Hyperplastic gastropathy}

Mucosal hypertrophy of the stomach due to epithelial hyperplasia can be divided into three types: (1) Zollinger-Ellison syndrome with glandular hyperplasia and hyperacidity, (2) Ménétrier's disease with mucous cell hyperplasia and protein loss and (3) mixed type with hyperplasia of all glandular elements. Gastric carcinoma may be present in the type 3 stomach. However, it has been postulated that the fundic mucosal hyperplasia observed in some of these patients may be secondary, caused by endocrine substances secreted by the tumor cells [60]. The patients tend to be young and female, and the carcinoma is often diffusely infiltrative. Zollinger-Ellison syndrome is not known to be associated with an increased incidence of gastric carcinoma. In Ménétrier's disease, the reported frequency of carcinoma is $5 \%-10 \%[27,61]$. The carcinoma may be located in grossly unremarkable antrum.

\section{Precancerous lesions: epithelial dysplasia}

Among the precancerous conditions listed above, only adenomas have a high rate of malignant transformation. Adenomas are characterized by the dysplastic nature of their component cells. Only a small percentage of other precursor conditions develop gastric carcinoma. These diverse conditions share one basic histological feature - the increased proliferative activity, or hyperplasia, of epithelial cells. Active epithelial hyperplasia may be considered the initial tissue alteration in the course of carcinogenesis. The pathologic lesion from which the carcinoma actually arises was largely unknown until the 1970s, when dysplasia of the epithelial cells was recognized as the ultimate precancerous lesion of gastric carcinoma [62].

As a precancerous condition, dysplasia is defined as a pathologic lesion characterized by pronounced cellular and structural alterations and showing a propensity to malignant transformation. It can occur in both metaplastic and nonmetaplastic glands. Based on the degree of abnormality, dysplasia has been classified simply into mild, moderate, and severe types (Figs. 5, 6).

Dysplasia is a dynamic process. In ten follow-up reports from 1984 to 1994, the average percent regression in mild, moderate, and severe dysplasia was $60 \%, 50 \%$, and $20 \%$, respectively, while the average percent regression in carcinoma was $2 \%, 20 \%$, and $60 \%$, respectively [23].

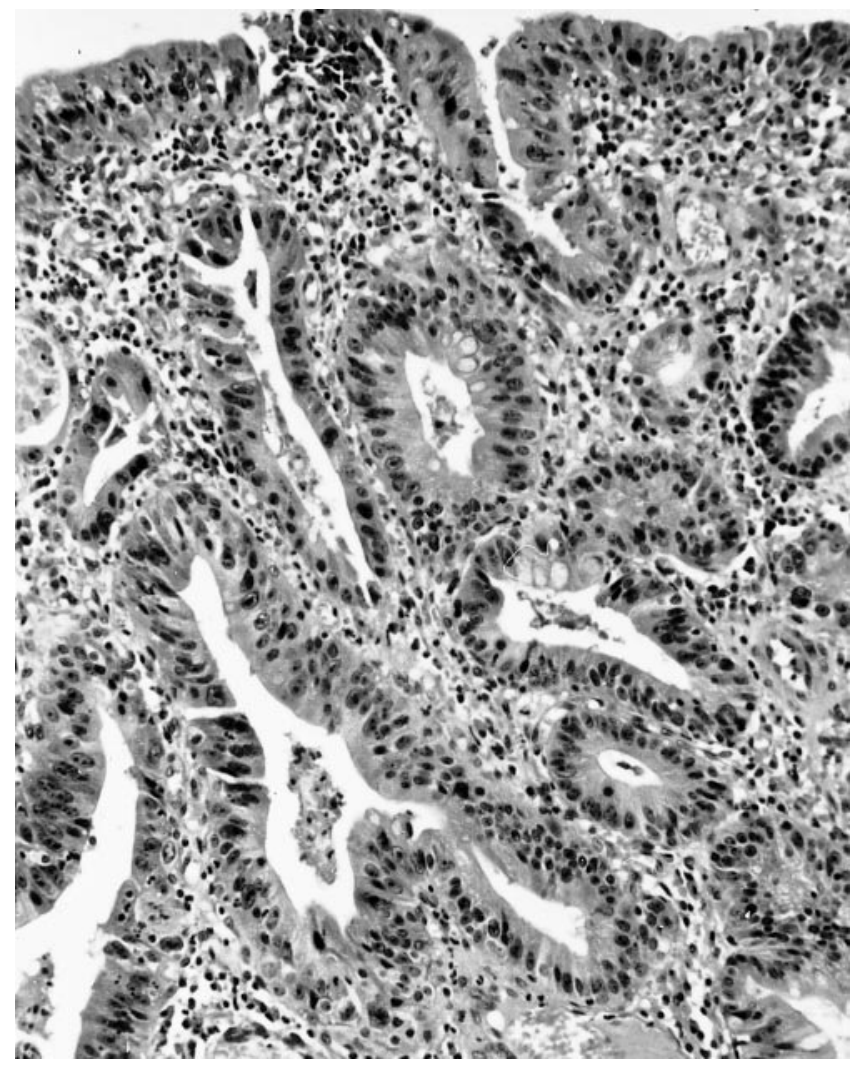

Fig. 5. Moderate epithelial dysplasia showing branching glands with prominent cellular stratification and pleomorphism. A few goblet cells are present. Chronic inflammation is prominent focally in the stroma. Hematoxylin and eosin stain. $\times 180$

Dysplastic cells have an increased amount of DNA, partly due to the increased number of proliferating cells and, when dysplasia is severe, polyploidy and aneuploidy are shown [41,42]. The nuclear area is enlarged [63], cell cycle time is lengthened, and the cell life span is shortened [64]. Carcinoembryonic antigen and occasionally, p21ras may be present [65]. The tumor suppressor gene $p 53$ and the apoptosis inhibitor $b c l-2$ gene may be overexpressed or mutated [33,34,66,67]. APC/ $M C C$ loss of heterozygosity was present in one third of reported cases of dysplasia [38]. These studies indicate that severely dysplastic cells resemble malignant cells, and may in fact be malignant already. Because of these findings, some investigators take the view that dysplasia is neoplastic. However, the dysplastic changes are multifocal, with unpredictable location. Dysplasia is asymptomatic and may regress [23]. DNA aneuploidy and $p 53$ alterations have also been found in clearly non-neoplastic epithelium with only chronic gastritis or intestinal metaplasia $[29,33,38,42]$. Nevertheless, histologic differentiation between moderate dysplasia and adenoma, and between severe dysplasia and in-situ car- 


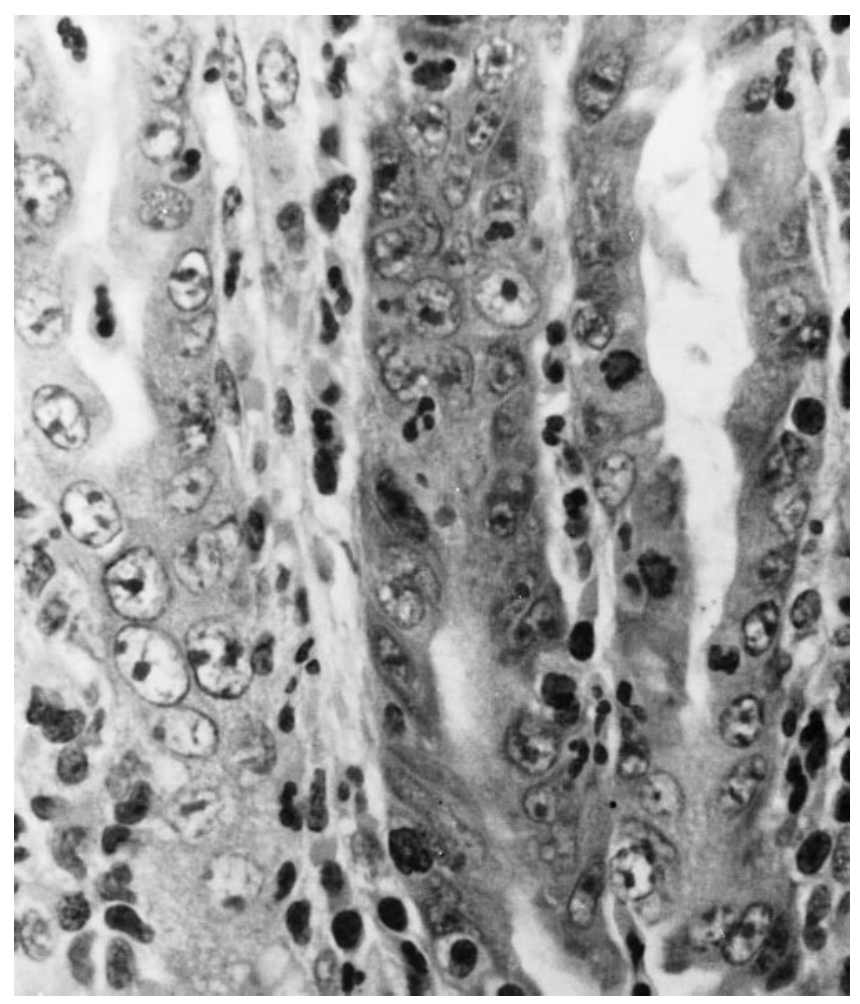

Fig. 6. Severely dysplastic glands showing enlarged nuclei with prominent nucleoli. The cytoplasm is markedly reduced. Mitoses are present. Hematoxylin and eosin stain. $\times 650$

cinoma may be difficult, particularly the latter. The decisive points are that dysplasia, defined as a precursor to malignancy, is a multifocal, ill-defined, and variable process, while a neoplasm is monoclonal, and thus, well defined and relatively uniform. Furthermore, the dysplastic cells do not invade, while carcinoma cells break through the basement membrane early (Fig. 4). Intramucosal stromal invasion is rarely absent when carcinoma is diagnosed. If the suspicion of carcinoma is strong, the patient should be closely followed by multiple and repeat biopsies to ascertain the diagnosis.

The majority of carcinomas found in follow-up studies were discovered within 1 year of the diagnosis of dysplasia [23], suggesting that the carcinoma was already present at the time of diagnosis of dysplasia. Most carcinomas were in the early stage and curable. Therefore, efforts must be made to search for any coexisting carcinoma, particularly if the dysplasia is severe or high grade.

Dysplasia of metaplastic tissue is closely associated with the expanding or intestinal type of cancer, but not with the infiltrative or diffuse cancer. The latter is more often associated with nonmetaplastic mucosa [68]. Its precise precancerous lesion remains uncertain. How- ever, there are indications that infiltrative carcinoma may arise from neck mucous cells or cells with globoid dysplasia [24]. In globoid dysplasia, the foveolar cells are engorged with excessive amounts of acidic mucin, compressing the eccentric nuclei, thus resembling signet-ring cells. The presence of acid mucin indicates that it is a form of incomplete intestinal metaplasia.

\section{Histologic features of gastric carcinoma}

The gastric mucosa and particularly its epithelial components, is a complex organ. In the presence of chronic inflammation, irrespective of the etiologic agent, the epithelium often shows intestinal metaplasia. Carcinomas may develop in either metaplastic or nonmetaplastic epithelium. Thus, carcinomas of the stomach have complex and heterogeneous cell populations and often contain both gastric and intestinal type cells. In addition, there may be endocrine cells and, less commonly, squamous cells [69].

Of the many types of cells identified in gastric carcinoma, mucous cells are common. The majority of them in glandular carcinoma are goblet cells secreting acidic mucins, as in the intestine [70,71]. In diffusely infiltrative carcinoma, most signet-ring cells are also goblet cells [71]. Many other cells, however, secrete gastric type mucin $[71,72]$. As the tumor progresses, the intestinal mucin increases [72]. Gastric type cells are also prominent in stump carcinoma [73]. The amount of mucus varies. The mucus is contained within the glandular structures in most instances. Excessive mucus may escape into the stroma. Non-mucous tumor cells are mostly immature absorptive cells, having a distinct striated border with well formed microvilli [71] and secreting digestive enzymes. Argyrophil cells are sometimes abundant in solid carcinomas [74] and diffusely infiltrating carcinomas [75]. Hepatoid alpha-fetoproteinproducing and human gonadotropin-secreting cells are present in rare tumors [76,77].

The stroma of many gastric carcinomas has distinctive features. Lymphocytic infiltration is prominent in some solid undifferentiated carcinomas. These lymphoepithelioma-like carcinomas have been associated with Epstein-Barr virus [24]. The amount of fibrous stromal tissue varies. It may be scanty in solid tumors called medullary carcinomas, and prominent in infiltrative tumors known as scirrhous carcinomas in which latter procollagen I has been demonstrated [78]. Transforming growth factor from tumor cells may stimulate both tumor cells and fibroblasts to produce collagen [79].

The blood and lymphatic vessels are essential for maintaining the viability of carcinomas. They also provide routes for the spread and metastasis of cancer cells. By immunohistochemical staining using antibody 
against factor VIII to outline the endothelium, the new small vessels can be counted. The microvessel count correlated with the extent of tumor invasion and lymph node and liver metastasis [80].

In general, the architectural features of gastric carcinomas fall into three groups: (1) Glandular carcinoma. This is the most common type of gastric carcinoma, with varying degrees of tubular differentiation, small-tomoderate amounts of fibrous stroma, and focal mononuclear inflammatory cells. Glandular carcinomas are commonly composed predominantly of intestinal type cells and rarely show a predominance of gastric cells. (2) Dispersed carcinoma. This type of carcinoma shows single or small groups of tumor cells or poorly formed glands dispersed in varying amounts of stromal fibrous tissue. Most such tumors are diagnosed at an advanced stage. In the early intramucosal or submucosal stage, the single tumor cells are often tightly packed without intervening fibrous stroma, but remain non-adherent to each other. Signet-ring cell carcinoma is the prototype of this carcinoma. (3) Solid carcinoma. This type of carcinoma is characterized by masses of cohesive tumor cells with no or only focal gland formation. There is often prominent lymphocytic accumulation in the intervening stroma. The solid tumor mass can be readily differentiated from the packed cells in early dispersed carcinoma.

\section{Histologic classification of gastric carcinoma}

The histologic composition of gastric carcinoma varies from patient to patient and from area to area in any patient. The common presence of several types of cells in the tumor makes it difficult to classify gastric carcinomas by cell type alone, except in rare occasions when a specific cell type dominates and presents as an unique clinicopathologic entity. Table 4 lists the types of carcinoma classified by the predominant cell type and structural presentation. In most instances, gastric carcinomas are classified according to the structural, growth, and invasive patterns. Several histological classifications have been proposed, each with specific features.

\section{Traditional histologic classification}

The World Health Organization (WHO) typing [81] is based on traditional histological criteria (Table 4). The adenocarcinomas are subdivided into papillary, tubular, signet-ring cell, and mucinous types. The carcinomas are further graded according to the degree of glandular differentiation. Undifferentiated carcinoma showing total lack of glandular or cellular differentiation is classified as a separate entity. This classification is useful for routine pathological diagnosis of gastric carcinoma.
Table 4. Histological classification of gastric carcinomas according to predominant cell type and structural presentation

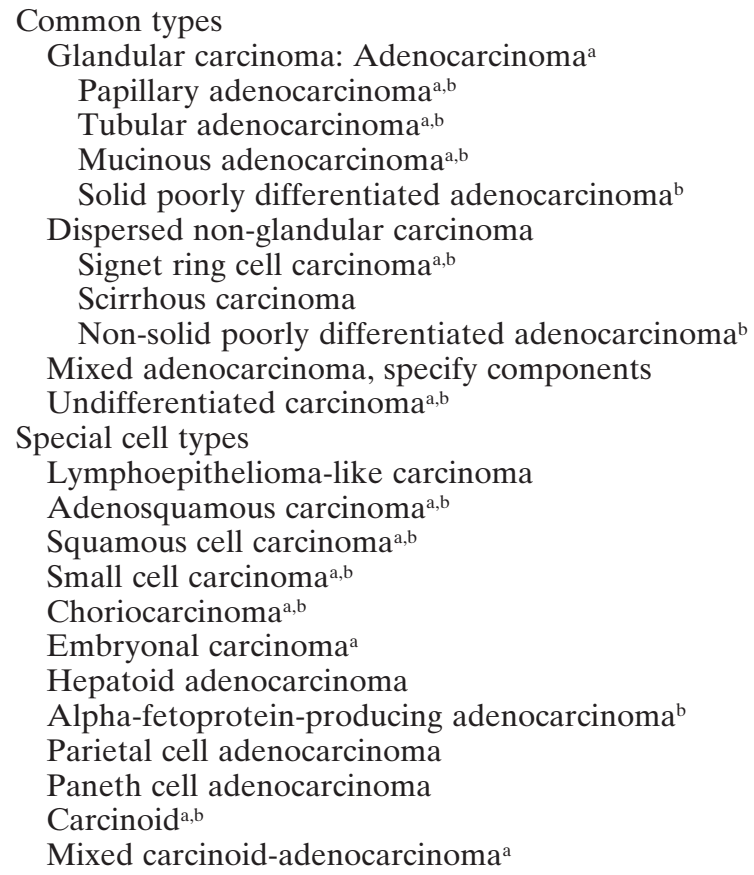

${ }^{a}$ Listed in World Health Organization [81] (WHO) classification.

${ }^{\mathrm{b}}$ Listed in Japanese classification by Japanese Research Society for Gastric Cancer [82]

The Japanese histological classification (Table 4) defined by the Japanese Research Society for Gastric Cancer (JRSGC) [82] divides gastric carcinoma into two major categories: Common type and special type, using histologic entities similar to the WHO classification, with the following differences. The well and moderately differentiated adenocarcinomas are subtypes of tubular adenocarcinoma. Poorly differentiated adenocarcinoma is a separate subtype and is subdivided into solid and nonsolid types. The solid tumors form discrete masses and the nonsolid type is a diffusely infiltrative tumor, but may have acinar or trabecular structures.

In a similar fashion, Nakamura [52] divided gastric cancers simply into differentiated and undifferentiated types, based on the degree of glandular differentiation. The undifferentiated carcinomas according to Nakamura include the poorly differentiated adenocarcinomas, as well as mucinous and signet-ring cell carcinomas, which are often composed of well differentiated cells. Thus, undifferentiated carcinoma according to Nakamura's classification is very different from the undifferentiated carcinoma according to the WHO classification.

In addition to histologic typing, the JRSGC classification includes the status of lymphatic and venous involvement, level of tumor penetration and metastasis, 
cancer-stroma relation, and pattern of tumor growth, as well as clinical and operative features. Thus, this classification facilitates tumor staging and evaluation of the patient's overall status.

\section{Classification by pattern of tumor growth and invasion}

Gastric carcinomas have different modes of growth. Many carcinoma cells maintain a coherent relationship with each other and form masses, as do adenocarcinomas of other organs, including those of the intestines. In about one-third to one-half of gastric carcinomas, the tumor cells show a loss of cohesive relationship and invade as individual or small groups of cells or glands. This phenomenon is rarely found in carcinomas of other organs. These variations manifest early and persist throughout the course. Thus, the growth and invasive patterns are intrinsic biologic characteristics of gastric cancer cells.

Laurén [83] was the first pathologist to recognize two distinct patterns of histologic composition and invasion, and divided gastric carcinomas into intestinal (53\%), diffuse $(33 \%)$, and unclassified (14\%) types. Recently, the term "mixed type" has been used to replace the "unclassified type". The respective frequencies of the three types in the American College of Surgeons survey [84] were $31 \%, 55 \%$, and $5 \%$. The mixed type tumors were treated as diffuse type in clinicopathological evaluations. The mixed type tumors are heterogeneous [85] and include tumors with mixed intestinal and diffuse types, diffuse carcinomas forming nodules, tumors with mixed glands and signet-ring cells, and some mucinous carcinomas.

Intestinal type carcinoma is characterized by the similarity of its histologic features with those of differentiated intestinal carcinoma, while diffuse type carcinoma shows diffuse infiltration of tumor cells individually or in small nests. Thus, these two tumor types are based on different criteria, which are not entirely compatible. In fact, the histologic types of carcinomas in the stomach and intestines according to the WHO classification are almost identical. Conversely, MUC5AC, a mucin specific for gastric foveolar and neck mucous cells, was present in $64 \%$ of gastric carcinomas, in $100 \%$ of early and in $59 \%$ of advanced gastric carcinomas. It was present in $59 \%$ of intestinal type and $83 \%$ of diffuse type carcinomas. It decreased as the tumor progressed and invaded deep into the tissue [86]. However, only intestinal type carcinoma is commonly associated with chronic atrophic gastritis, severe intestinal metaplasia, and dysplasia in the neighboring mucosa.

Recognizing the differences in the patterns of tumor growth and invasiveness among the gastric carcinomas, Ming [87] proposed a classification of gastric carcinomas into expanding and infiltrative types (Table 5). Ex-
Table 5. Pathologic features of classification of invasive gastric carcinoma by growth pattern [87]

\begin{tabular}{lll}
\hline & \multicolumn{2}{c}{ Type } \\
\cline { 2 - 3 } Features & Expanding & Infiltrative \\
\hline Gross form & & \\
Superficial & Most cases & \\
Polypoid & Few cases \\
Fungating & All cases & None \\
Ulcerated & Most cases & Few cases \\
Diffuse & Half cases & Half cases \\
Cancer cells & Few cases & Most cases \\
Gland formation & & \\
Size of glands & Common & Uncommon \\
Differentiation & Mostly large & Mostly small \\
Aggregated masses & Variable & Variable \\
Goblet cells & Common & Uncommon \\
Mucus & Common & Common \\
Neutral mucoprotein & Rare & \\
Acidic mucin & Common & Common \\
Extracellular pool & Occasional & Occasional \\
Stroma & & \\
Inflammatory cells & Common & Uncommon \\
Fibrosis & Slight & Prominent \\
Neighboring mucosa & & \\
Atrophy & Common & Occasional \\
Intestinal metaplasia & Severe & Mild or none \\
Dysplasia & Common & Rare \\
\hline
\end{tabular}

$\overline{{ }^{a} \text { Growth and invasive pattern of most superficial gastric carcinomas }}$ are not yet evident

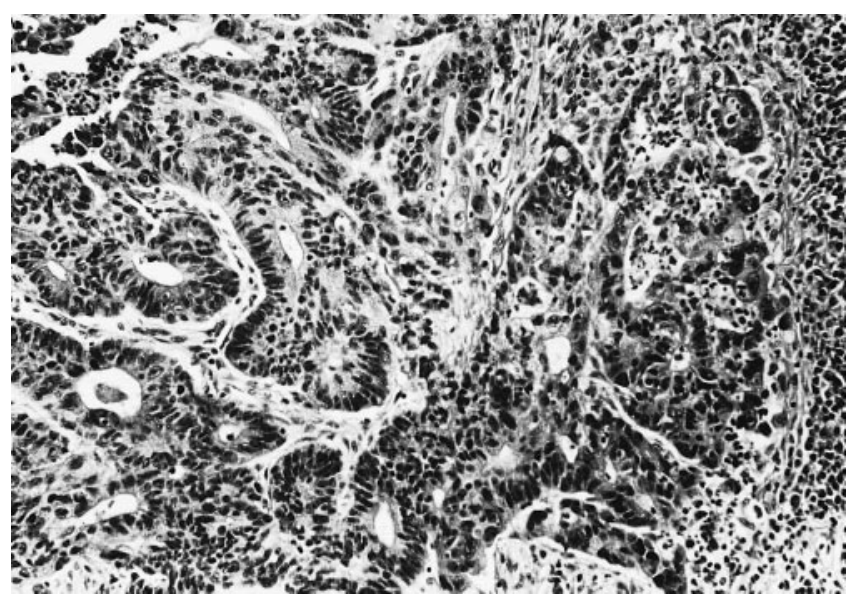

Fig. 7. Expanding type adenocarcinoma consisting of a compact patch of moderately differentiated neoplastic glands, scanty fibrous stroma, and focal lymphocytic accumulation. Hematoxylin and eosin stain. $\times 150$

panding carcinomas (Figs. 7, 8) grow by expansion of cohesive tumor nodules or masses, with a well defined periphery. Infiltrative carcinoma cells grow independently into dispersed separate individual cells or small 


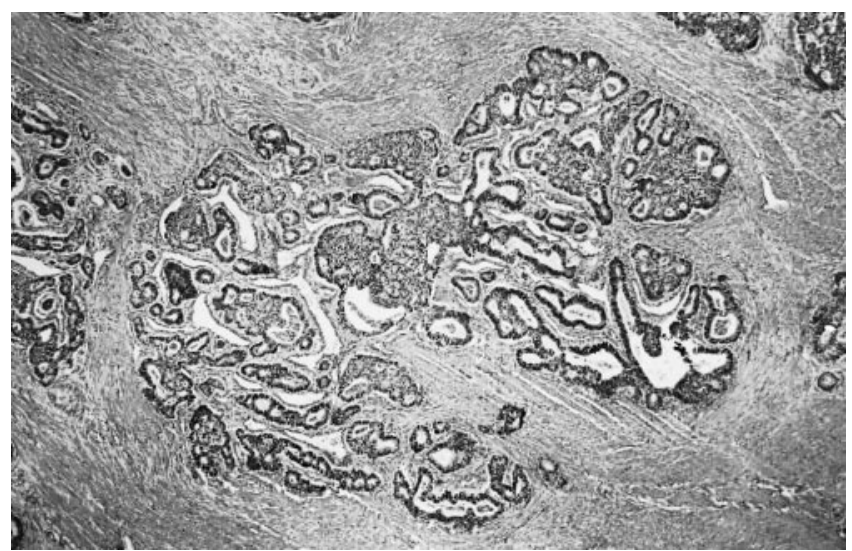

Fig. 8. Expanding type adenocarcinoma showing aggregated glandular carcinoma forming a circumscribed nodule. Hematoxylin and eosin stain. $\times 65$

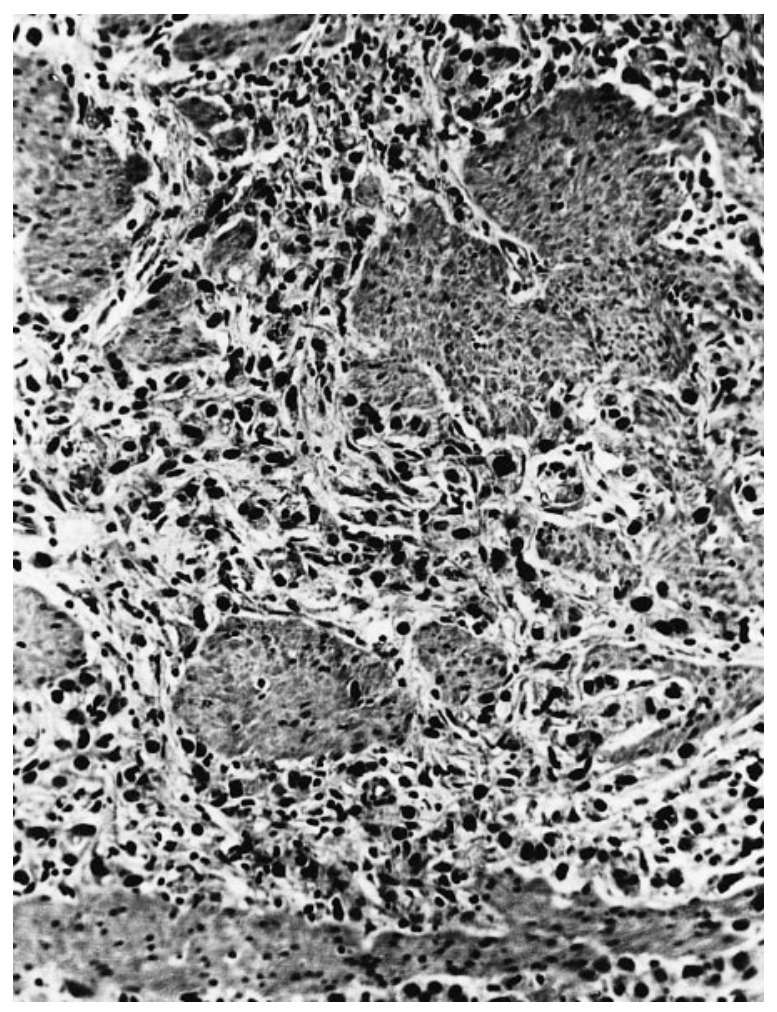

Fig. 9. Infiltrative type carcinoma showing individual neoplastic cells, mostly undifferentiated, infiltrating the fibrous stroma between smooth muscle bundles of the muscularis propria. Hematoxylin and eosin stain. $\times 200$

glands (Figs. 9-11) that show strong invasive power with extensive infiltration into the stroma (Fig. 9). The relative frequencies of these types are $65 \%$ and $30 \%$, respectively. The growth patterns are mixed in $5 \%$ of tumors; $2 \%$ with prominent expanding pattern and $3 \%$ with prominent infiltrative pattern. Some expanding tu-

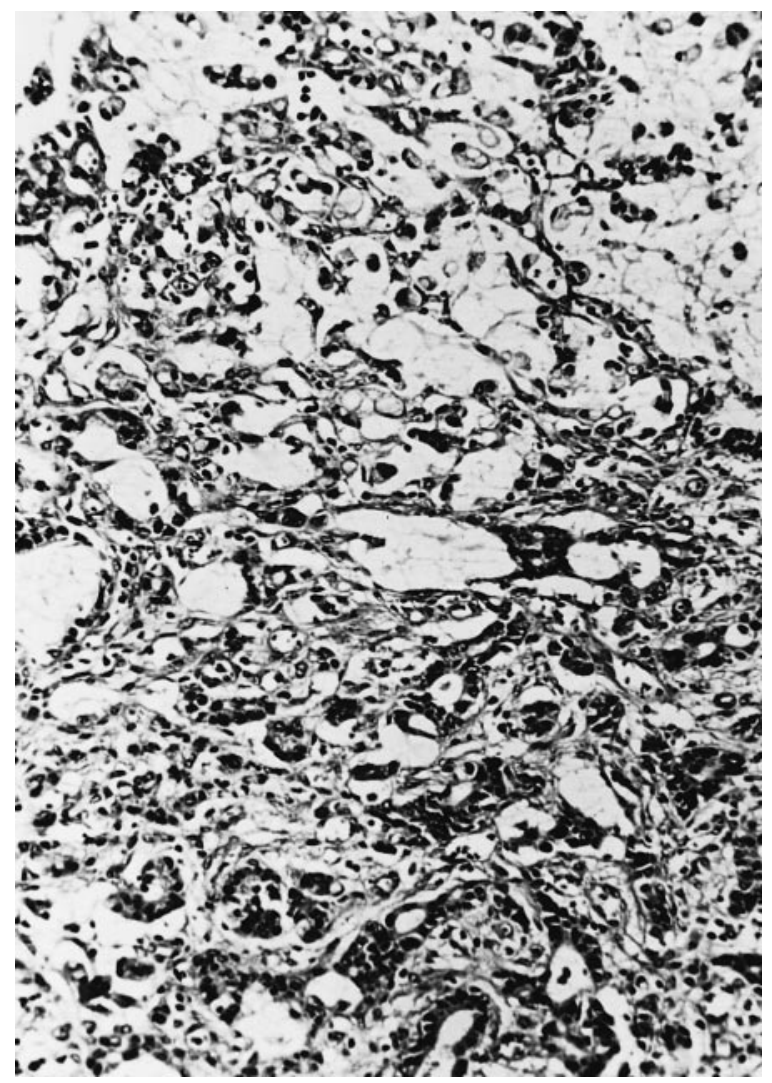

Fig. 10. Infiltrative adenocarcinoma with irregular neoplastic tubules in the lower portion and signet-ring cell tumor in small mucinous pools. Hematoxylin and eosin stain. $\times 150$

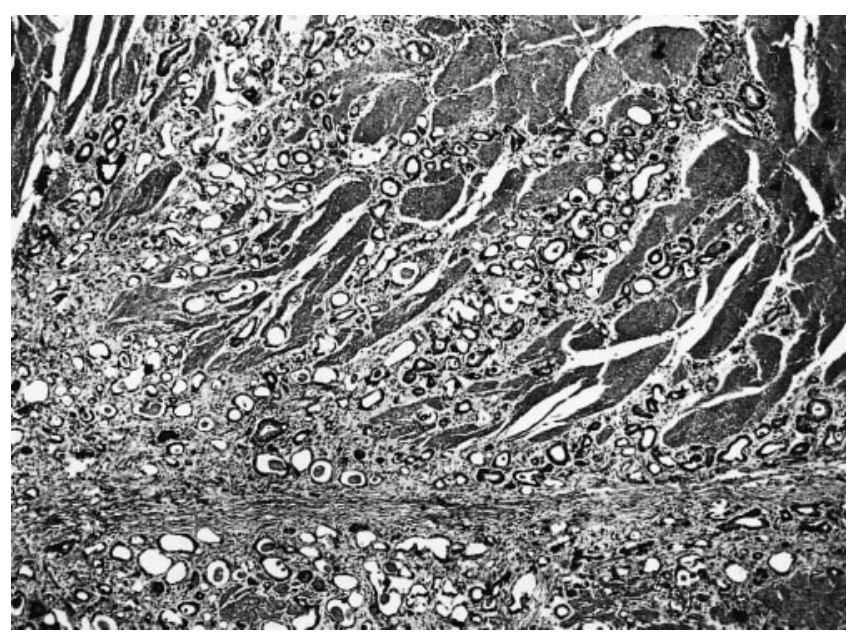

Fig. 11. Infiltrative carcinoma showing well formed small glands infiltrating the muscularis propria. Fibrous stroma is prominent in the lower portion. Hematoxylin and eosin stain. $\times 65$ 
mors show an infiltrative growth pattern at their advancing margin, reflecting increased malignancy of the tumor. However, the designation of tumor type should be based on the growth pattern of the entire tumor. If the infiltrative pattern is limited to the periphery of the tumor, the basic biology of the carcinoma may have not been substantially altered.

The different modes of tumor growth are the basis for the gross appearance of the tumor. Polypoid and fungating carcinomas are typical of expanding carcinomas, and diffusely infiltrative carcinomas are formed by non-cohesive infiltrative tumor cells. Grossly ulcerative carcinomas are about equally divided between expanding and infiltrative growth patterns.

Grossly The growth patterns of gastric carcinomas are related to the loss of function of cell adhesion molecules such as E-cadherin, which is preserved in expanding carcinomas and lost in infiltrative carcinoma [88]. Electron microscopy revealed well developed desmosomes in expanding, but not infiltrative carcinoma [89]. Lymphocytic infiltration is heavy in expanding carcinoma and desmoplastic response is prominent in infiltrative carcinoma.

Ming's classification places primary emphasis on the patterns of growth and invasion. Each main type contains tumors with different grades of cellular and glandular differentiation, which also influence the biologic behavior of the tumor. Thus, each main type should be further classified into well differentiated and poorly differentiated subtypes. These subtypes may change as the tumor progresses with increasing loss of differentiation.

There are similarities between Ming's and Laurén's classifications. Expanding carcinomas are mostly intestinal type and the infiltrative carcinomas are usually diffuse type carcinomas. However, the solid carcinoma, unclassified according to Laurén's classification, is an expanding carcinoma. Conversely, a tumor composed of small glands and infiltrating diffusely is an infiltrative type carcinoma. Furthermore, the well differentiated carcinoma of Nakamura's classification [52] generally grows by expansion and the poorly differentiated carcinoma grows by infiltration.

\section{Other classifications}

Inokuchi and Sugimachi [90] divided early gastric carcinomas into superficial (Super) and penetrating (Pen) types. The latter is further divided into A and B types. Pen A tumors show expanding type growth and Pen B tumors, infiltrative type growth. Similar patterns were noted in the advanced carcinomas. These types were related to prognosis. The Super type had good prognosis and Pen A type poor prognosis. The prognosis of early Pen B carcinomas was good but worsened in the late stage [90]. Mulligan [91] divided gastric carcinomas into mucous cell $(46.7 \%)$, pylorocardiac gland cell (29.7\%), and intestinal cell (23.6\%) types. Goseki et al. [92] classified gastric carcinomas into four groups based on the degree of tubular differentiation and amount of intracellular mucus. This classification has been correlated with the extent of metastasis.

\section{Molecular alterations in gastric carcinoma}

Many molecules, including oncogenes, growth factors, tumor suppressor genes, and other regulatory genes and proteins participate in the development of gastric carcinoma. The development of monoclonal antibodies and advances in molecular technology have greatly expanded the scope of investigation.

DNA content and ploidy patterns have been studied in both early and advanced gastric carcinomas. In the early carcinomas studied in Japan using cytophotometry, high DNA ploidy was found in $37 \%$ [93]; in only $9 \%-16 \%$ of superficial carcinoma, in $30 \%$ of Pen B type, and in $82 \%-94 \%$ of Pen A type [90,93]. Similar distribution patterns were observed in the advanced stages of these tumor types. The frequency of high DNA ploidy fluctuated as the differentiated carcinomas invaded deep into the tissue, ranging from $43 \%$ to $71 \%$, while the frequency of high DNA ploidy in undifferentiated carcinoma increased steadily from $0 \%$ in mucosal carcinoma to $58 \%$ in serosal carcinoma [90]. Using flow cytometry in the carcinomas of European patients [94], aneuploidy was noted in $50 \%$ of superficial early carcinomas, in $70 \%$ of Pen A type, and in $41 \%$ of Pen B type. It was present in $45 \%$ of tubular carcinomas and $17 \%$ of signet-ring carcinomas. In advanced carcinomas, aneuploidy was found in 34\%-73\% [94-98]; more frequently in glandular than nonglandular tumors [29,90,96]. Heterogeneity of ploidy pattern was noted in about $30 \%$ of early and advanced differentiated carcinomas, and in $60 \%$ of advanced, but in none of early undifferentiated carcinomas [95]. In $32 \%$ of adranced tumors, the superficial portion was diploid and the deep portion aneuploid [97]. This phenomenon is particularly evident in signet-ring cell carcinoma $[94,98]$ and correlates with the slow growth of such early tumors in both humans and animals $[99,100]$.

The polyploid and aneuploid carcinomas had high cell proliferation activity and positive expression of epidermal growth factor receptor. They were more advanced and had worse prognosis than diploid tumors and tumors with homogeneous ploidy $[95,96,101]$.

There have been many molecular studies of gastric carcinoma. The results are well summarized by Tahara et al. [102] and others [103]. Microsatellite instability (MI) with replication error (RER + phenotype) is common in gastric carcinomas, often involving many loci [32]. Ad- 
Table 6. Microsatellite instability in gastric carcinoma (\%)

\begin{tabular}{|c|c|c|c|c|c|c|c|c|c|c|c|}
\hline \multicolumn{3}{|c|}{ Early CA } & \multicolumn{8}{|c|}{ Advanced/Unspecified CA } & \multirow[b]{2}{*}{ Reference number } \\
\hline Total & In & Di & Total & WD & PD & SR & $\mathrm{Sc}$ & Sol & In & Di & \\
\hline \multirow[t]{8}{*}{12} & 19 & 4 & 19 & & & & & & 30 & 6 & 104 \\
\hline & & & 33 & 33 & 18 & & 75 & & & & 30 \\
\hline & & & 47 & & & & & & & & 31 \\
\hline & & & 22 & & & & & & 30 & 6 & 106 \\
\hline & & & & 17 & & & & & & & 32 \\
\hline & & & & $25-67^{a}$ & & & & & & & 32 \\
\hline & & & $0^{\mathrm{b}}$ & & & & & & & & 109 \\
\hline & & & $60^{c}$ & & & & & & & & 102 \\
\hline \multirow[t]{2}{*}{$15^{\mathrm{d}}$} & & & & & & $17^{\mathrm{d}}$ & & & & & 98 \\
\hline & & & & 17 & 64 & 21 & & & & & 107 \\
\hline \multirow[t]{3}{*}{12} & & & 33 & & & 9 & & 47 & 40 & & 105 \\
\hline & & & 40 & & & & & & & & 115 \\
\hline & & & 31 & 33 & 26 & 100 & & & & & 108 \\
\hline
\end{tabular}

CA, carcinoma; In, intestinal type; Di, diffuse type; WD, well differentiated; PD, poorly differentiated; SR, signet-ring cell type; Sc, scirrhous type; Sol, solid type.

a At different loci.

b Ages 19-39 years.

Age under 35 years.

${ }^{\mathrm{d}}$ All signet-ring cell carcinomas

vanced carcinomas are more likely to show MI than early carcinoma [104,105] (Table 6). Although some reports showed a higher frequency of MI in intestinal type and well differentiated carcinoma than in diffuse type carcinoma [104,106], others reported higher frequency in poorly differentiated [107], signet-ring cell [108], and scirrhous carcinomas [30]. In one report, MI was found in $60 \%$ of carcinomas in patients under 35 years of age [102], but in another report MI was not found in any patients between 19 and 39 years of age [109]. MI was shown in $47 \%$ of solid carcinomas, but MI was not detected in EBV-positive tumors [105]. Patients with a family history of gastric carcinoma had higher rates of MI in the tumor [110-112]. Germline mutations at loci involved in hereditary nonpolyposis colorectal cancers, such as hMSH2 and hMLH1, were not detected in gastric carcinoma [113]. In synchronous multiple gastric carcinomas, the status of MI was found to be heterogeneous, indicating different pathways in their development [114]. MI has not been clearly related to any clinical or pathological feature of gastric carcinomas [115].

The tumor suppressor $p 53$ gene has been examined in many studies. Selected results of some of the reports are included in Table 7. Overexpression and mutation of $p 53$ were seen more frequently in the intestinal type than in diffuse type carcinomas $[116,117]$ and more in the differentiated than the undifferentiated carcinomas $[29,117,119,120]$. The alterations occur early and remain at the same level in the intestinal type carcinomas [118]. They are infrequent in early diffuse carcinomas, but increase progressively as the tumor advances $[18,118,121]$. The frequency of $p 53$ changes has been related to metastasis $[119,122,123]$, DNA ploidy
[119,124], and cohesiveness of tumor growth [125]. p53 alterations were related to the depth of invasion in some reports [34,126], but not in others $[117,127,128]$. There is no relation between the growth pattern of the tumor and expression of $p 53$ [34,118]. The 5-year survival rate was $9 \%$ for carcinomas with $p 53$ mutation and $42 \%$ for those without mutation [129], but the survival rate was not affected by the mere expression of $p 53$ [130].

Mutation and loss of heterozygosity ( $\mathrm{LOH}$ ) of tumor suppressor genes involved in the colonic carcinogenesis, such as APC (adenomatous polyposis coli), MCC ( tated in colorectal cancer) and DCC (deleted in colorectal cancer) have also been found in gastric carcinomas. $A P C$ and $M C C$ are located close to each other on chromosome 5q. DCC is located on chromosome 18q. Mutation and $\mathrm{LOH}$ of $A P C$ were observed in $1 \%-34 \%$ of carcinomas, of $M C C$ in $41 \%-58 \%$, and of $A P C / M C C$ in $31 \%-$ $84 \%[36,38,105,131]$. The rates of $\mathrm{LOH}$ were lower than the mutation rates, and rates of $\mathrm{LOH}$ and mutation of APC and MCC were lower in well differentiated than in poorly differentiated carcinomas [131]. In one report, $D C C$ mutation was seen in $58 \%$ of carcinomas [36]. In another report [126], DCC mutation was found in $28 \%$ of carcinomas; $18 \%$ in well differentiated and $10 \%$ in poorly differentiated carcinomas. $\mathrm{LOH}$ of $D C C$ was seen in $61 \%$ of carcinomas, and occurred more frequently in early-stage than late-stage tumors [126]. In multiple synchronous carcinomas, $A P C, M C C$, and $p 53$ had different mutation patterns, suggesting separate pathways of tumor development [132].

The apoptosis inhibitor $b c l-2$ gene was expressed in $14 \%$ of gastric carcinomas; in $21 \%$ of early carcinomas, in $8 \%$ of advanced carcinomas, in $17 \%$ of well differen- 
Table 7. $p 53$ Mutation or overexpression in gastric carcinomas (\%)

\begin{tabular}{|c|c|c|c|c|c|c|c|c|c|}
\hline \multirow[b]{3}{*}{ Gene alteration } & \multicolumn{7}{|c|}{ Carcinoma types } & & \multirow[b]{3}{*}{ Reference number } \\
\hline & \multicolumn{2}{|c|}{ Early } & \multicolumn{6}{|c|}{ Advanced } & \\
\hline & Int & Diff & WD & PD & Int & Diff & SRC & Muc & \\
\hline Overexpression & 70 & 52 & & & & & & & 116 \\
\hline Mutation & 41 & 4 & & & 50 & 33 & & & 118 \\
\hline Overexpression & & & 64 & 33 & 56 & 27 & 20 & 50 & 117 \\
\hline Overexpression & & & 50 & 46 & & & 0 & 4 & 119 \\
\hline Overexpression & & & 54 & 0 & & & & & 120 \\
\hline Mutation & & & 21 & & & & & & 120 \\
\hline \multirow[t]{2}{*}{ Overexpression } & & & 73 & 52 & & & & & 29 \\
\hline & \multicolumn{4}{|c|}{ Primary } & \multicolumn{3}{|c|}{ Metastatic } & & \\
\hline $\mathrm{LOH}$ & \multicolumn{4}{|c|}{25} & \multicolumn{3}{|c|}{44} & & 122 \\
\hline Mutation & \multicolumn{4}{|c|}{0} & \multicolumn{3}{|c|}{50} & & 123 \\
\hline Expression & \multicolumn{4}{|c|}{54} & \multicolumn{3}{|c|}{85} & & 119 \\
\hline & \multicolumn{4}{|c|}{ Diploid } & \multicolumn{3}{|c|}{ Aneuploid } & & \\
\hline Mutation & \multicolumn{4}{|c|}{0} & \multicolumn{3}{|c|}{64} & & 124 \\
\hline Overexpression & \multicolumn{4}{|c|}{31} & \multicolumn{3}{|c|}{69} & & 119 \\
\hline & \multicolumn{4}{|c|}{ Cohesive } & \multicolumn{3}{|c|}{ Non-cohesive } & & \\
\hline Mutation & \multicolumn{4}{|c|}{37} & \multicolumn{3}{|c|}{0} & & 125 \\
\hline
\end{tabular}

Int, Intestinal type, Diff, diffuse type; WD, well differentiated; PD, poorly differentiated; SRC, signet-ring cell type; Muc, mucinous type

tiated, and in $10 \%$ of poorly differentiated carcinomas [133]. It is interesting to note that, in another report [134], bcl-2 expression was present in $24 \%$ of well differentiated and in none of poorly differentiated carcinomas, whereas the corresponding rates of $b c l-2 \mathrm{LOH}$ were reversed: $b c l-x L$, also an inhibitor of cell death, was over-expressed in $63 \%$ of early carcinomas and $50 \%$ of advanced carcinomas [135]. The bax gene, an antagonist of $b c l-2$ and thus promoter of apoptotic cell death, was reported to be mutated in $64 \%$ of gastric carcinomas with microsatellite instability [136]. The anti-metastasis $n m 23$ gene was expressed in $85 \%$ of gastric carcinomas, and was twice as frequent in the intestinal type as in the diffuse type carcinomas [137]. $n m 23 \mathrm{LOH}$ was found in $24 \%$ of colon cancers [138]. nm23 was decreased in lymph node metastasis and serosal carcinomas [139]. Aberrant variants of CD44, a cell adhesion molecule implicated in tumor progression and metastasis, were present in all gastric carcinomas [140]. Another cell adhesion molecule, E-cadherin, was lost in $0 \%-13 \%$ of well differentiated and expanding carcinomas and in $40 \%-50 \%$ of poorly differentiated and infiltrative carcinomas [140,141]. Vascular endothelial growth factor, which is related to angiogenesis in tumors and metastases, is more frequently expressed in differentiated than in undifferentiated carcinomas [140].

The cell proliferation regulator, cyclin E, was overexpressed in $29 \%$ of gastric carcinomas [142]. Proliferative cell nuclear antigen was expressed in $90 \%$ of carcinomas [128] and Ki67 immunoreactivity was in- creased in deep-seated tumors and lymph node metastasis [143]. p16, a product of multiple tumor suppressor gene, was not mutated or deleted in gastric carcinoma [144], but aberrant RNA transcripts were found in $46 \%$ of diffuse type carcinomas and $30 \%$ of intestinal type carcinomas [145]. p21 (WAF-1), an inhibitor of cyclin-dependent kinases, was expressed in $32 \%$ of carcinomas; patients with these tumors had a better survival rate than patients whose tumors were without this expression [130].

Several oncogenes have been demonstrated in gastric carcinomas [140,146]. K-sam appears to be specific for poorly differentiated and scirrhous carcinomas. The cmet gene is also more frequently amplified in scirrhous carcinoma [147]. On the other hand, the c-erbB2 gene, amplified in $18 \%-24 \%$ of gastric cancers $[128,148]$, is expressed in differentiated carcinomas. K-ras gene mutation is rarely reported $[36,39,149,150]$. In one report of 44 tumors, point mutation of K-ras was found in 2 and of $\mathrm{N}$-ras in 3 diffuse type carcinomas [150].

Several growth factors are expressed in gastric carcinomas [151]. Over-expression of epithelial growth factor (EGF) is associated more often with well differentiated than with poorly differentiated carcinoma, while transforming growth factor (TGF) $\beta$ is seen more often in the latter. In $83 \%-91 \%$ of gastric carcinomas with microsatellite instability, there is mutation of TGF $\beta$ RII [106,152], thus reducing inhibition of the ability of TGF $\beta$ to stimulate tumor growth. In one report, such a mutation was not seen in gastric carcinomas, although it was present in $81 \%$ of colorectal carcinomas [153]. 
Table 8. Genetic alterations in gastric and colon carcinomas (\%)

\begin{tabular}{|c|c|c|c|c|}
\hline \multirow[b]{2}{*}{ Genes } & \multicolumn{2}{|c|}{ Gastric cancer ${ }^{140}$} & \multicolumn{2}{|c|}{ Colon cancer } \\
\hline & WD & PD & Sporadic $^{43}$ & $\mathrm{UC}^{154}$ \\
\hline Replication error & $17^{107}-40^{105 \mathrm{~W}}$ & $9^{105 X Y}-75^{29 X}$ & $45^{155}$ & 83 \\
\hline Telomerase activity & 100 & 90 & $94^{102}$ & \\
\hline CD44 (abnormal transcript) & 100 & 100 & $100^{156}$ & \\
\hline p53 (LOH, mutation) & $42^{126}-60$ & 75 & $75-85$ & $50^{157}-100$ \\
\hline nm23 (overexpression) & $97137 \mathrm{X}$ & $54^{137 Z}$ & & \\
\hline$(\mathrm{LOH})$ & & & $24^{138}$ & \\
\hline$V E G F$ (overexpression) & 46 & 12 & & \\
\hline Cyclin $E$ (amplification) & 20 & 10 & $9^{158}$ & \\
\hline $\mathrm{K}$-ras (mutation) & 10 & 0 & 48 & $30^{157}-50$ \\
\hline$b c l-2(\mathrm{LOH})$ & $24^{134}-43$ & $0^{134,140}$ & $60^{134}$ & \\
\hline (overexpression) & $0^{134}$ & $24^{134}$ & & \\
\hline$c$-erb $B-2$ (amplification) & 20 & 0 & $<5$ & \\
\hline$K$-sam (amplification) & 0 & $33^{\mathrm{x}}$ & & \\
\hline Cadherin/catenin (loss) & $0-13^{87}$ & $40^{87}-50$ & $44^{141}$ & \\
\hline c-met (amplification) & $19^{147}$ & $20^{147 x}-39^{142}$ & $3^{147}$ & \\
\hline TGF $\beta R I I$ (mutation) & $91^{106}$ & & $81^{153}$ & $17^{153}$ \\
\hline$A P C$ (LOH, mutation) & $22^{131}-60$ & $0-43^{131}$ & $>65$ & $33^{154,159}$ \\
\hline$D C C(\mathrm{LOH})$ & $50-61^{156}$ & 0 & $70-75$ & \\
\hline$M C C$ (LOH, mutation) & $20^{131}$ & $60^{131}$ & $10-50$ & $29^{159}$ \\
\hline
\end{tabular}

Carcinoma type: WD, Well differentiated; PD, poorly differentiated; W, intestinal type; X, scirrhous type; Y, signet-ring cell type; Z, diffuse type; UC, Ulcerative colitis-associated cancer

The above review reveals many differences in the molecular alterations between the well differentiated and poorly differentiated gastric carcinomas, as observed by Tahara et al $[102,140]$. Some of these findings are summarized in Table 8 . It should be noted that poorly differentiated carcinomas in the Japanese classification correspond to diffuse type carcinoma and include infiltrative non-glandular tumors such as signetring cell carcinomas and scirrhous carcinoma (see the section on histologic classification above). The well differentiated carcinomas are mainly intestinal type carcinomas. Genetic alterations common in both intestinal and diffuse types of carcinomas are RER + phenotype, telomerase activity, CD44 variant transcripts, and p53 mutation. Changes which occur more frequently in well differentiated carcinoma are mutations of the $A P C$ and $D C C$ genes, and genes related to apoptosis and metastasis. E-cadherin loss occurs almost exclusively in the poorly differentiated carcinomas.

Since intestinal type carcinoma of the stomach resembles colonic carcinoma, it is possible that the molecular alterations in these tumors are similar [125]. The respective molecular features are compared in Table 8 . In this Table, the sporadic colorectal carcinomas are non-hereditary tumors. Ulcerative colitis-associated colorectal carcinomas are also listed for comparison, because most gastric carcinomas occur in stomachs with chronic gastritis, a condition analogous to ulcerative colitis.
The molecular events common to both gastric and colon carcinomas are telomerase activity, aberrant transcripts of CD44, and mutation of TGF $\beta$ RII in unstable carcinomas, suggesting the fundamental role of these changes in gastrointestinal carcinogenesis. Mutations of the $A P C, D C C$, and $M C C$ genes in well differentiated gastric carcinomas are similar to those in sporadic colorectal carcinomas. There is no similarity between these changes in gastric carcinoma and the changes in ulcerative colitis-associated colorectal cancer. In reality, there is no solid reason to expect a definitive parallel between the carcinogenic process of gastric carcinoma and that of colonic carcinoma. In view of the observation that even in the same stomach, multiple synchronous tumors have different patterns of molecular alterations [114,132], it is not surprising that carcinomas in two different organs, though similar, retain separate characteristics.

The concept of intestinal type carcinoma in the stomach was developed when knowledge of the carcinogenic process was limited. Nevertheless, it has long been recognized, including by Laurén, that intestinal type carcinoma in the stomach is unlike carcinoma of the colon, in that both intestinal and diffuse carcinomas of the stomach consist of intestinal and gastric types of cells $[83,87,160,161]$, and intestinal type carcinoma is related to incomplete metaplasia, which has mixed intestinal and gastric features. The molecular changes re-enforce the view that intestinal type gastric carcinoma is quite 
Table 9. Immunohistochemical reactivity of EGF, EGF-R and p53 in gastric carcinoma $(\%)$

\begin{tabular}{|c|c|c|c|c|c|c|c|c|c|c|c|}
\hline \multirow[b]{2}{*}{ Carcinoma type } & \multicolumn{2}{|c|}{$\begin{array}{l}\text { Number } \\
\text { of cases }\end{array}$} & \multicolumn{3}{|c|}{$E G F$} & \multicolumn{3}{|c|}{$E G F-R$} & \multicolumn{3}{|c|}{ p53 } \\
\hline & A & B & 0 & + & ++ & 0 & + & ++ & 0 & + & ++ \\
\hline All carcinomas & 64 & 45 & 27 & 39 & 34 & 17 & 36 & 47 & 36 & 31 & 33 \\
\hline Expanding type & 39 & 21 & 26 & 33 & 41 & 13 & 38 & 49 & 38 & 33 & 29 \\
\hline WD & 24 & 14 & 17 & 25 & 58 & 13 & 53 & 54 & 36 & 36 & 28 \\
\hline $\mathrm{PD}$ & 15 & 7 & 40 & 47 & 13 & 13 & 58 & 29 & 43 & 28 & 29 \\
\hline Infiltrative type & 25 & 24 & 28 & 48 & 24 & 24 & 40 & 36 & 33 & 29 & 38 \\
\hline WD & 17 & 12 & 29 & 59 & 12 & 30 & 53 & 17 & 58 & 25 & 17 \\
\hline PD & 5 & 12 & 25 & 25 & 50 & 12 & 13 & 75 & 8 & 34 & 58 \\
\hline
\end{tabular}

0 , Absent; + , weakly reactive; ++ , strongly reactive; $\mathrm{WD}$, well differentiated; $\mathrm{PD}$, poorly differentiated.

Number of cases: A, In epidermal growth factor $(E G F)$ and $E G F$-receptor $(R)$ studies; B, In $p 53$ studies

different from true colonic carcinoma. It should be treated rightfully as a form of gastric carcinoma and be studied in its own right.

The reported molecular studies show many inconsistent, sometimes conflicting, results, making it difficult to evaluate the significance of the data. One possible cause is technical. The data on gene expression gained by immunohistochemical staining may be expected to differ from data on mutation gained by molecular analysis. Another reason for inconsistency may be the nature of the specimen used for analysis. Most reports did not state the amount of viable tumor tissue in the specimen and the histologic features of the tumor. Most carcinomas contain various amounts of heterogeneous tissue which may vary in their biologic characteristics. In order to ascertain the nature of tissue in the specimen, a microscopic examination of the tissue under study is required. The importance of knowing the detailed histologic features of the tumor is exemplified in our studies on the immunohistochemical expression of $p 53$ and epidermal growth factor and its receptor, shown in Table 9. The crude data show similarity in the results for expanding and infiltrative carcinomas. When the grade of differentiation is taken into account, distinct differences become apparent between these two groups.

\section{Future perspectives}

Advances in clinical diagnosis and management have greatly improved the survival of patients suffering from gastric cancer. The etiology of this disease and the causative carcinogens remain to be ascertained, however. The development of molecular technology has enhanced our understanding of the mechanisms of development and progression of the cancer. Thus far, the information is fragmentary and, at times, conflicting.
It is clear that much more effort is needed to unravel the mystery. The data suggest that gastric cancer may have multiple routes of development. In this regard, the pathological diversity of the tumor has been instrumental in suggesting this possibility. The effort in broadening the search for pathological clues to correlate with the molecular biology of the tumor should be expanded.

The pathological study of gastric cancer has been intense and comprehensive. More importantly, it has evolved from mere morphologic description to conceptual and biologic investigation. The transition began when it was recognized that there were two main types of gastric cancer. With the information from molecular studies, it is now evident that each main type has multiple variations, or subtypes. There may also be other cancer types distinct from these recognized groups. Therefore, it is important to strengthen our efforts of closely correlating the morphologic and molecular data and providing new understanding of the basic mechanisms and manifestations of gastric cancer. To facilitate the interpretation of the results, a standard should be set with regard to the detailed pathologic classification and the scope of molecular investigation. Such efforts will inevitably further improve the clinical management and benefit the patients.

\section{References}

1. Neugut AI, Hayek M, Howe G. Epidemiology of gastric cancer. Semin Oncol 1995;23:281-91.

2. Parker SL, Tong T, Bolden S, Wingo PA. Cancer statistics, 1997. CA Cancer J Clin 1997;47:5-27.

3. Kosary CL, Ries LAG, Miller BA, Hankey BF, Harras A, Edwards BK. SEER cancer statistics review, 1973-1992: Tables and graphs. Bethesda: National Cancer Institute. NIH Publication No. 96-2789, 1996. 
4. Nomura A, Grove JS, Stemmerimann GN, Severson RK. A prospective study of stomach cancer and its relation to diet, cigarettes, and alcohol consumption. Cancer Res 1990;50:627-31.

5. Aoki K. Epidemiology of stomach cancer. In: Nishi M, Ichikawa H, Nakajima T, Maruyama K, Tahara E, editors. Gastric cancer. Tokyo: Springer-Verlag; 1993:2-15.

6. Munoz SE, Ferraroni M, La Vecchia C, Decarli A. Gastric cancer risk factors in subjects with family history. Cancer Epidemiol Biomarkers Prev 1997;6:137-40.

7. Harrison LE, Zhang ZF, Karpeh MS, Sun M, Kurtz RC. The role of dietary factors in the intestinal and diffuse histologic subtypes of gastric adenocarcinoma: A case-control study in the U.S. Cancer 1997;80:1021-8.

8. Leach SA, Thompson M, Hill M. Bacterially catalysed Nnitrosation reactions and their relative importance in the human stomach. Carcinogenesis 1987;8:1907-12.

9. Sipponen P. Helicobacter pylori: A cohort phenomenon. Am J Surg Pathol 1995;19(Suppl 1):S30-6.

10. Crespi M, Citarda F. Helicobacter pylori and gastric cancer: An overrated risk? Scand J Gastroenterol 1996;31:1041-6.

11. Graham DY, Go MF. Helicobacter pylori: Current status. Gastroenterology 1993;105:279-82.

12. Solcia E, Fiocca R, Luinetti O, Villani L, Padovan L, Calistri D, et al. Intestinal and diffuse gastric cancers arise in a different background of Helicobacter pylori gastritis through different gene involvement. Am J Surg Pathol 1996;20(Suppl 1):S8-22.

13. Vollmers HP, Dammrich J, Ribbert H, et al. Human monoclonal antibodies from stomach carcinoma patients react with Helicobacter pylori and stimulate stomach cancer cells in vitro. Cancer 1994;74:1525-32.

14. Blaser MJ, Perez-Perez GI, Kleanthous H, et al. Infection with Helicobacter pylori strains possessing cagA is associated with an increased risk of developing adenocarcinoma of the stomach. Cancer Res 1995;55:2111-5.

15. Mitchell HM, Hazell SL, Li YY, Hu PJ. Serological response to specific Helicobacter pylori antigens: Antibody against CagA antigen is not predictive of gastric cancer in a developing country. Am J Gastroenterol 1996;91:1785-8.

16. Endo S, Ohkusa T, Saito Y, Fujiki K, Okayasu I, Sato C. Detection of Helicobacter pylori infection in early stage gastric cancer. A comparison between intestinal- and diffuse-type gastric adenocarcinomas. Cancer 1995;75:2203-8.

17. Wee A, Kang JY, The M. Helicobacter pylori and gastric cancer: Correlation with gastritis, intestinal metaplasia and tumour histology. Gut 1993;33:1029-32.

18. Wu MS, Shun CT, Wang HP, Sheu JC, Lee WJ, Wang TH, et al. Genetic alterations in gastric cancer: Relation to histological subtypes, tumor stage, and Helicobacter pylori infection. Gastroenterology 1997;112:1457-65.

19. Cahill RJ, Xia H, Kilgallen, Beattie S, Hamilton H, O’Morain C. Effect of eradication of Helicobacter pylori infection on gastric epithelial cell proliferation. Dig Dis Sci 1995;40:1627-31.

20. Borody TJ, Clark IW, Andrews P, Hugh TB, Shortis NP. Eradication of Helicobacter pylori may not reverse severe gastric dysplasia. Am J Gastroenterol 1995;90:498-9.

21. Genta RM, Gurer IE, Graham DY, Krishnan B, Segura AM, Gutierrez O, et al. Adherence of Helicobacter pylori to areas of incomplete intestinal metaplasia in the gastric mucosa. Gastroenterology 1996;111:1206-11.

22. Nakamura S, Ueki T, Yao T, Ueyama T, Tsuneyoshi M. EpsteinBarr virus in gastric carcinoma with lymphoid stroma. Special reference to its detection by the polymerase chain reaction and in situ hybridization in 99 tumors, including a morphologic analysis. Cancer 1994;73:2239-49.

23. Ming SC, Hirota T. Malignant epithelial tumors of the stomach. In: Ming SC, Goldman H, editors. Pathology of the gastrointestinal tract. 2nd edn. Baltimore: William and Wilkins, 1998:607-47.

24. Borchard F. Precancerous conditions and lesions of the stomach. In: Rugge M, Arslan-Pagnini C, DiMario F, editors. Carcinoma gastrico e lesioni precancerose dello stomaco. Milano: Edizioni Unicopi, 1986:175-210.

25. Gad A. Carcinoma of the resected stomach. In: Ming SC, editor. Precursors of gastric cancer. Philadelphia: Praeger, 1984;287313.

26. Ming SC. The classification and significance of gastric polyps. In: Yardley JH, Morson BM. eds. The gastrointestinal tract. Baltimore: Williams and Wilkins, 1977:149-75.

27. Martin ED. Frequency and evolution of precancerous and dysplastic lesions in the stomach. Excerpta Med Int Congr Ser 1981;555:225-30.

28. Toyooka M, Konishi M, Kikuchi-Yanoshita R, Iwama T, Miyaki M. Somatic mutations of the adenomatous polyposis coli gene in gastroduodenal tumors from patients with familial adenomatous polyposis. Cancer Res 1995;55:3165-70.

29. Kitayama Y, Sugimura H, Tanaka M, Nakamura S, Kino I. Expression of p53 and flow cytometric DNA analysis of isolated neoplastic glands of the stomach: An application of the gland isolation method. Virchows Arch A Pathol Anat Histol 1995; 426:557-62.

30. Semba S, Yokozaki H, Yamamoto S, Yasui W, Tahara E. Microsatellite instability in precancerous lesions and adenocarcinomas of the stomach. Cancer 1996;77(Suppl 8):1620-7.

31. Hamamoto T, Yokozaki H, Semba S, Yasui W, Yunotani S, Miyazaki K, et al. Altered microsatellites in incomplete-type intestinal metaplasia adjacent to primary gastric cancers. J Clin Pathol 1997;50:841-6.

32. Tamura G, Sakata K, Maesawa C, Suzuki Y, Terashima M, Satoh K, et al. Microsatellite alterations in adenoma and differentiated adenocarcinoma of the stomach. Cancer Res 1995; 55:1933-6.

33. Shiao Y-H, Rugge M, Correa P, Lehmann HP, Scheer WD. p53 alteration in gastric precancerous lesions. Am J Pathol 1994;144:511-7.

34. Brito MJ, Williams GT, Thompson H, Filipe MI. Expression of p53 in early (T1) gastric carcinoma and precancerous adjacent mucosa. Gut 1994;35:1697-700.

35. Tohdo H, Yokozaki H, Haruma K, Kajiyama G, Tahara E. p53 gene mutations in gastric adenomas. Virchows Arch B Cell Pathol 1993;63:191-5.

36. Maesawa C, Tamura G, Suzuki Y, Ogasawara S, Sakata K, Kashiwaba M, et al. The sequential accumulation of genetic alterations characteristic of the colorectal adenoma-carcinoma sequence does not occur between gastric adenoma and adenocarcinoma [see comments]. J Pathol 1995;176:249-58.

37. Nakatsuru S, Yanagisawa A, Furukawa Y, Ichii S, Kato Y, Nakamura Y, et al. Somatic mutations of the APC gene in precancerous lesion of the stomach. Hum Mol Genet 1993;2:1463-5.

38. Sanz-Ortega J, Sanz-Esponera J, Caldes T, Gomez de la Concha E, Sobel ME, Merino MJ. LOH at the APC/MCC gene (5Q21) in gastric cancer and preneoplastic lesions. Prognostic implications. Pathol Res Pract 1996;192:1206-10.

39. Tsuchiya C, Ohshima S, Takahama M. Detection of c-Ki-ras oncogene mutation in gastric adenomas with formalin-fixed, paraffin-embedded biopsy materials. J Gastroenterol 1997; 32:28-33.

40. Kuniyasu H, Domen T, Hamamoto T, Yokozaki H, Yasui W, Tahara H, et al. Expression of human telomerase RNA is an early event of stomach carcinogenesis. Jpn J Cancer Res 1997;88:103-7.

41. Macartney JC, Camplejohn RS. DNA flow cytometry of histological material from dysplastic lesions of human gastric mucosa. J Pathol 1986;150:113-8.

42. Abdel-Wahab M, Attallah AM, Elshal MF, Eldousoky I, Zalata KR, el-Ghawalby NA, et al. Correlation between endoscopy, histopathology, and DNA flow cytometry in patients with gastric dyspepsia. Hepatogastroenterology 1996;43:131320. 
43. Tamura G, Sakata K, Nishizuka S, Maesawa C, Suzuki Y, Terashima M, et al. Allellotype of adenoma and differentiated adenocarcinoma of the stomach. J Pathol 1996;180:371-7.

44. Fearon ER. Molecular abnormalities in colon and rectal cancer. In: Mendelsohn J, Israel MA, Liotta LA, editors. The molecular basis of cancer. Philadelphia: WB Saunders, 1995:340-57.

45. Sugimura T. Experimental gastric cancer. In: Nishi M, Ichikawa H, Nakajima T, Maruyama K, Tahara E, editors. Gastric cancer. Tokyo: Springer-Verlag, 1993:28-39.

46. Ming SC, Yu PL. Histogenesis of experimental colonic carcinoma. In: Rozen P, Reich CB, Winawer SJ, editors. Large bowel cancer: Policy, prevention, research and treatment. Front Gastrointest Res 1991;18:200-24.

47. Cheli R, Giocosa A, Pirasso A. Chronic gastritis: A dynamic process toward cancer. In: Ming S-C, editor. Precursors of gastric cancer. New York: Praeger Scientific, 1984:117-29.

48. Lipkin M, Correa P, Mikol YB, Higgins PJ, Cuello C, Zarama $\mathrm{G}$, et al. Proliferative and antigenic modifications in human epithelial cells in chronic atrophic gastritis. J Natl Cancer Inst 1985;75:613-9.

49. Ming SC. Intestinal metaplasia: Its heterogeneous nature and significance. In: Ming SC, editor. Precursors of gastric cancer. Philadelphia: Praeger, 1984:219-31.

50. Jass JR, Filipe MI. The mucin profile of normal gastric mucosa, intestinal metaplasia and its variants and gastric carcinoma. Histochemi J 1981;13:931-9.

51. Ramesar KC, Sanders DS, Hopwood D. Limited value of type III intestinal metaplasia in predicting risk of gastric carcinoma. J Clin Pathol 1987;40:1287-90.

52. Nakamura K. Histogenesis of the gastric carcinoma and its clinico-pathological significance. In: Nishi $M$, Ichikawa $\mathrm{H}$, Nakajima T, Maruyama K, Tahara E, editors. Gastric cancer. Tokyo: Springer-Verlag; 1993:112-32.

53. Watanabe H, Ito A. Relationship between gastric tumorigenesis and intestinal metaplasia in rats given $\mathrm{X}$-radiation and/or $\mathrm{N}$-methyl-N'-nitro-N-nitrosoguanidine. J Natl Cancer Inst 1986;76:865-70.

54. Arikawa J, Tokunaga M, Satoh E, Tanaka S, Land CE. Morphological characteristics of Epstein-Barr virus-related early gastric carcinoma: A case-control study. Pathol Internat 1997;47:360-7.

55. Rollag A, Jacobsen CD. Gastric ulcer and risk of cancer. A 5-year follow-up study. Acta Med Scand 1984;216:105-9.

56. Kawai K, Kizu M, Miyaoka T. Epidemiology and pathogenesis of gastric cancer. Front Gastrointest Res 1980;6:71-86.

57. Safatle-Ribeiro AV, Ribeiro Junior U, Reynolds JC, GamaRodrigues JJ, Iriya K, Kim R, et al. Morphologic, histologic, and molecular similarities between adenocarcinomas arising in the gastric stump and the intact stomach. Cancer 1996;78:2288-99.

58. Watt PC, Sloan JM, Spencer A, Kennedy TL. Histology of the postoperative stomach before and after diversion of bile. BMJ (Clin Res) 1983;287:1410-2.

59. Tokudome S, Kono S, Ikeda M, et al. A prospective study on primary gastric stump cancer following partial gastrectomy for benign gastroduodenal diseases. Cancer Res 1984;44:2208-12.

60. Stamm B, Saremaslani P. Coincidence of fundic glandular hyperplasia and carcinoma of the stomach. Cancer 1989;63: 354-9.

61. Antonioli DA. Precursors of gastric carcinoma: A critical review with a brief description of early (curable) gastric cancer. Hum Pathol 1994;25:994-1005.

62. Ming SC, Bajtai A, Correa P, et al. Gastric dysplasia. Significance and pathologic criteria. Cancer 1984;54:1794-801.

63. Jarvis LR, Whitehead R. Morphometric analysis of gastric dysplasia. J Pathol 1985;147:133-8.

64. Oehlert W. Preneoplastic lesions of the stomach. In: Ming SC. editor. Precursors of gastric cancer. New York: Praeger; 1984: 73-82.

65. Li J, Zhao A, Lu Y, Wang Y. Expression of p185erbB2 and p21ras in carcinoma, dysplasia, and intestinal metaplasia of the stomach: An immunohistochemical and in situ hybridizaton study. Semin Surg Oncol 1994;10:95-9.

66. Brito MJ, Williams GT, Thompson H, Filipe MI. Expression of p53 in early (T1) gastric carcinoma and precancerous adjacent mucosa. Gut 1994;35:1697-700.

67. Lauwers GY, Scott GV, Hendricks J. Immunohistochemical evidence of aberrant bcl-2 protein expression in gastric epithelial dysplasia. Cancer 1994;73:2900-4.

68. Chang H-K, Huh M-H. Relationship of histologic types of early gastric cancer and types of gastric dysplasia. In: Siewert JR, Roder JD, editors. Progress in gastric cancer research 1997. Bologna: Monduzzi Editore, 1997:811-4.

69. Sasano N, Nakamura K, Arai M, Akazaki K. Ultrastructural cell patterns in human gastric carcinoma compared with nonneoplastic gastric mucosa - histogenetic analysis of carcinoma by mucin histochemistry. J Natl Cancer Inst 1969;43:783-802.

70. Ming SC. Tumors of the esophagus and stomach. In: Atlas of tumor pathology, second series, fascicle 7. Washington DC: Armed Forces Institute of Pathology; 1973:144-206.

71. Fiocca R, Villani L, Tenti P, Solcia E, Corraggia M, Frigerio B, et al. Characterization of four main cell types in gastric cancer: Foveolar, mucopeptic, intestinal columnar and goblet cells. An histologic, histochemical and ultrastructural study of "early" and "advanced" tumours. Pathol Res Pract 1987;182:308-25.

72. Yamachika T, Inada K, Fujimitsu Y, Nakamura S, Yamamura Y, Kitou $\mathrm{T}$, et al. Intestinalization of gastric signet-ring cell carcinomas with progression. Virchows Arch A Pathol Anat Histol 1997;431:103-10.

73. Yokoyama K, Hattori T. Characteristics and development of stump cancers of the stomach (in Japanese). Nippon Shokakibyo Gakkai Zasshi (Jpn J Gastroenterol) 1995;92:761-8.

74. Murayama H, Imai T, Kikuchi M. Solid carcinomas of the stomach. A combined histochemical, light and electron microscopic study. Cancer 1983;51:1673-81.

75. Tahara E, Ito H, Nakagami K, et al. Scirrhous argyrophil cell carcinoma of the stomach with multiple production of polypeptide hormones, amine, CEA, lysozyme, and HCG. Cancer 1982;49:1904-15.

76. Nagai E, Ueyama T, Yao T, Tsuneyoshi M. Hepatoid adenocarcinoma of the stomach. A clinicopathologic and immunohistochemical analysis. Cancer 1993;72:1827-35.

78. Niitsu Y, Ito N, Kohda K, Owada M, Morita K, Sato S, et al. Immunohistochemical identification of type I procollagen in tumor cells of scirrhous adenocarcinoma of the stomach. Br J Cancer 1988;57:79-82.

79. Yoshida K, Yokozaki H, Nimoto M, Ito H, Ito M, Tahara E, et al. Expression of TGF- $\beta$ and procollagen type I and type III in human gastric carcinomas. Int J Cancer 1989;44:394-8.

80. Araya M, Terashima M, Takagane A, Abe K, Nishizuka S, Yonezawa $\mathrm{H}$, et al. Microvessel count predicts metastasis and prognosis in patients with gastric cancer. J Surg Oncol 1997;65:232-6.

81. Watanabe H, Jass JR, Sabin LH. Histological typing of oesophageal and gastric tumours. In: World Health Organization international histological classification of tumours. 2nd edn. (no editors). Berlin: Springer-Verlag; 1989:20-6.

82. Japanese Research Society for Gastric Cancer. Japanese classification of gastric cancer. Tokyo: Kanehara; 1995.

83. Laurén P. The two histological main types of gastric carcinoma. Diffuse and so-called intestinal type carcinoma. An attempt at histoclinical classification. Acta Pathol Microbiol Scand 1965;64:31-49.

84. Wanebo HJ, Kennedy BJ, Chmiel J, Steele G Jr, Winchester $\mathrm{D}$, Osteen R. Cancer of the stomach. A patient care study by the American College of Surgeons. Ann Surg 1993;218:58392.

85. Stelzner S, Emmrich P. The mixed type in Laurén's classification of gastric carcinoma. Histologic description and biologic behavior. Gen Diagn Pathol 1997;143:39-48. 
86. Reis CA, David L, Nielsen PA, Clausen H, Mirgorodskaya K, Roepstorff $\mathrm{P}$, et al. Immunohistochemical study of MUC5AC expression in human gastric carcinomas using a novel monoclonal antibody. Int J Cancer 1997;74:112-21.

87. Ming SC. Gastric carcinoma: A pathobiological classification. Cancer 1977;39:2475-85.

88. Wang R-N, Cai J-C, Jiang C-Y, Jiang S-J. Role of cell adhesion molecules in determining glandular differentiation and growth pattern of gastric carcinoma. Cell Vision 1995;2:120-5.

89. Ming SC. Tumors of the esophagus and stomach. Supplement. In: Atlas of tumor pathology, second series, fascicle 7. Washington DC: Armed Forces Institue of Pathology, 1985:533-54.

90. Inokuchi K, Sugimachi K. Growth patterns of gastric cancer. In: Nishi M, Ichikawa H, Nakajima T, Maruyama K, Tahara E, editors. Gastric cancer. Tokyo: Springer-Verlag, 1993:88-101.

91. Mulligan, RM. Histogenesis and biological behavior of gastric carcinoma. Pathol Annu 1972;7:349-415.

92. Goseki N, Takizawa T, Koike M. Differences in the mode of extension of gastric cancer classified bv histological type: New histological classification of gastric carcinoma. Gut 1992;33:60612.

93. Haraguchi M, Korenaga D, Kakeji Y, Orita H, Maehara Y, Sugimachi K. DNA ploidy is associated with growth potential in gastric carcinoma. Cancer 1991;68:2608-11.

94. Brito MJ, Filipe MI, Williams GT, Thompson H, Ormerod MG, Titley J. DNA ploidy in early gastric carcinoma (T1): A flow cytometric study of 100 European cases. Gut 1993;34:2304.

95. Hattori T. DNA ploidy pattern and cell kinetics. In: Nishi M, Ichikawa H, Nakajima T, Maruyama K, Tahara E, editors. Gastric cancer. Tokyo: Springer-Verlag, 1993:184-95.

96. Rugge M, Sonego F, Panozzo M, et al. Pathology and ploidy in the prognosis of gastric cancer with no extranodal metastasis. Cancer 1994;73:1127-33.

97. Imada T, Yamamoto Y, Fukuzawa K, Rino Y, Suda T, Moriwaki $\mathrm{Y}$, et al. Flow cytometric analysis of nuclear DNA heterogeneity in gastric cancer. Jpn J Clin Oncol 1997;27:221-6.

98. Kimura T, Sato H, Manabe R, Konishi H, Kushima R, Sugihara $\mathrm{H}$, et al. Analysis of microsatellite regions and DNA ploidy pattern in signet-ring cell carcinomas of the stomach (in Japanese). Gan To Kagaku Ryoho (Jpn J Cancer Chemother) 1997;24(Suppl 2):273-8.

99. Fujita, S. Natural history of human gastric carcinomas in terms of their genesis and progression. Asian Med J 1983;26:787-805.

100. Szentirmay Z, Ohgaki H, Maruyama K, Esumi H, Takayama S, Sugimura T. Early gastric cancer induced by $\mathrm{N}$-ethyl-N' - nitro-Nnitrosoguanidine in a Cynomolgus monkey 6 years after initial diagnosis of the lesion. Jpn J Cancer Res 1990;81:6-9.

101. Korenaga D, Okamura T, Saito A, Baba H, Sugimachi K. DNA ploidy is closely linked to tumor invasion, lymph node metastasis, and prognosis in clinical gastric cancer. Cancer 1988;62:309-13.

102. Tahara E, Semba S, Tahara H. Molecular biological observations in gastric cancer. Semin Oncol 1995;23:307-15.

103. Wright PA, Williams GT. Molecular biology and gastric carcinoma. Gut 1993:34:145-7.

104. Buonsanti G, Calistri D, Padovan L, Luinetti O, Fiocca R, Solcia E, et al. Microsatellite instability in intestinal- and diffuse-type gastric carcinoma. J Pathol 1997;82:167-73.

105. Chong J-M, Fukayama M, Hayashi Y, et al. Microsatellite instability in the progression of gastric carcinoma. Cancer Res 1994;54:4595-7.

106. Chung YJ, Song JM, Lee JY, Jung YT, Seo EJ, Choi SW, et al. Microsatellite instability-associated mutations associate preferentially with the intestinal type of primary gastric carcinomas in a high-risk population. Cancer Res 1996;56:4662-5.

107. Han H-J, Yanagisawa A, Kato Y, Park J-G, Nakamura Y. Genetic instability in pancreatic cancer and poorly differentiated type of gastric cancer. Cancer Res 1993;53:5087-9.
108. Rhyu M-G, Park W-S, Meltzer SJ. Microsatellite instability occurs frequently in human gastric carcinoma. Oncogene 1994;9:29-32.

109. Hayden JD, Cawkwell L, Sue-Ling H, Johnston D, Dixon MF, Quirke P, et al. Assessment of microsatellite alterations in young patients with gastric adenocarcinoma. Cancer 1997;79:684-7.

110. Keller G, Vogelsang H, Rudelius M, Grimm V, Mueller J, Siewert JR, et al. Characterization of microsatellite instability and mutation analysis of the DNA mismatch repair genes $h M L H 1$ and $h M S H 2$ in familial gastric cancer. In: Siewert JR, Roder JD, editors. Progress in gastric cancer research 1997. Bologna: Monduzzi Editore, 1997:475-80.

111. Ottini L, Palli D, Falchetti M, D'Amico C, Amorosi A, Saieva C, et al. Microsatellite instability in gastric cancer is associated with tumor location and family history in a high-risk population from Tuscany. Cancer Res 1997;57:4523-9.

112. Vogelsang HE, Keller G, Grimm V, Mueller J, Siewert JR, Hofler. Microsatellite instability and positive family anamnesis in patients with stomach carcinoma (in German). Langenbecks Arch Chir Suppl Kongressbd 1997;114:113-6.

113. Akiyama $\mathrm{Y}$, Nakasaki H, Nihei Z, Iwama T, Nomizu T, Utsunomiya $\mathrm{J}$, et al. Frequent microsatellite instabilities and analyses of the related genes in familial gastric cancers. Jpn J Cancer Res 1996;87:595-601.

114. Nakashima H, Inoue H, Honda M, Shibuta K, Arinaga S, Mori $\mathrm{M}$, et al. The heterogeneity of microsatellite instability in multiple gastric cancers. Am J Gastroenterol 1995;90:653-6.

115. Noguchi T, Muller W, Wirtz H-C, Scheven M, Ruschoff J, Hommel G, et al. Microsatellite instability in gastric cancer: Correlation with clinicopathologic parameters and prognosis. In: Siewert JR, Roder JD, editors. Progress in gastric cancer research 1997. Bologna: Monduzzi Editore, 1997:491-8.

116. Craanen ME, Blok P, Dekker W, Offerhaus GJA, Tytgat GNJ. Chronology of p53 protein accumulation in gastric carcinogenesis. Gut 1995;36:848-52.

117. Fukunaga M, Monden T, Nakanishi H, Ohne M, Fukuda K, Tomita N, et al. Immunohistochemical study of p53 in gastric carcinoma. Am J Clin Pathol 1994;101:177-80.

118. Ranzani GN, Luinetti O, Padovan LS, Calistri D, Renault B, Burrel M, et al. p53 gene mutations and protein nuclear accumulation are early events in intestinal type gastric cancer but late events in diffuse type. Cancer Epidemiol Biomarkers Prev 1995;4:223-31.

119. Kakeji Y, Korenaga D, Tsujitani S, Baba H, Anai H, Maehara Y, et al. Gastric cancer with p53 overexpression has high potential for metastasizing to lymph nodes. Br J Cancer 1993;67: 589-93.

120. Gomyo Y, Osaki M, Kaibara N, Ito H. Numerical aberration and point mutation of $p 53$ gene in human gastric intestinal metaplasia and well-differentiated adenocarcinoma: Analysis by fluorescence in situ hybridization (FISH) and PCR-SSCP. Int J Cancer 1996;66:594-9.

121. Roviello F, Marrelli D, Messano A, Vindigni C, Filipe MI, Gallorini M, et al. Clinical importance of p53, PCNA and EGFr expression in resected gastric cancer. In: Siewert JR, Roder JD, eds. Progress in gastric cancer research 1997. Bologna: Monduzzi Editore, 1997:537-42.

122. Kim JH, Takahashi T, Chiba I, Park JG, Bierrer MJ, Roh JK, et al. Occurrence of $p 53$ gene abnormalities in gastric carcinoma tumors and cell lines. J Natl Cancer Inst 1991;83:938-43.

123. Yamada Y, Yoshida T, Hayashi K, Sekiya T, Yokota J, Hirohashi $\mathrm{S}$, et al. p53 gene mutations in gastric cancer metastases and in gastric cancer cell lines derived from metastases. Cancer Res 1991;51:5800-5.

124. Tamura G, Kihana T, Nomura K, Terada M, Sugimura T, Hirohashi $\mathrm{T}$, et al. Detection of frequent $p 53$ gene mutations in primary gastric cancer by cell sorting and polymerase chain reaction single-strand conformation polymorphism analysis. Cancer Res 1991;51:3056-8. 
125. Uchino S, Noguchi M, Ochiai A, Saito T, Kobayachi M, Hirohashi S, et al. p53 mutation in gastric cancer: A genetic model for carcinogenesis is common to gastric and colorectal cancer. Int J Cancer 1993;54:759-64.

126. Uchino S, Tsuda H, Noguchi M, Yokota J, Terada M, Saito T, et al. Frequent loss of heterozygosity at the DCC locus in gastric cancer. Cancer Res 1992;52:3099-102.

127. Seruca R, David L, Holm R, Nesland JM, Fangan BM, Costdo S, et al. p53 mutations in gastric carcinomas. $\mathrm{Br} \mathrm{J}$ Cancer 1992;65:708-10.

128. Chen BF, Marrogi AJ, Freeman SM, Clejan S. Gastric carcinoma: Recent issues in prognostic factors. J La State Med Soc 1995; 147:138-45.

129. Lim BHG, Soong R, Grieu F, Robbins PD, House AK, Iacopetta BJ. p53 accumulation and mutation are prognostic indicators of poor survival in human gastric carcinoma. Int $\mathrm{J}$ Cancer 1996;69;200-4.

130. Gomyo Y, Ikeda M, Osaki M, Tatebe S, Tsujitani S, Ikeguchi M, et al. Expression of $\mathrm{p} 21$ (waf1/cip1/sdi1), but not p53 protein, is a factor in the surval of patients with advanced gastric carcinoma. Cancer 1997;79:2067-72.

131. McKie AB, Filipe MI, Lemoine NR. Abnormalities affecting the $A P C$ and $M C C$ tumour suppressor gene loci on chromosome $5 \mathrm{q}$ occur frequently in gastric cancer but not in pancreatic cancer. Int J Cancer 1993;55:598-603.

132. Kang GH, Kim CJ, Kim WH, Kang YK, Kim HO, Kim YI. Genetic evidence for the multicentric origin of synchronous multiple gastric carcinoma. Lab Invest 1997;76:407-17.

133. Saegusa M, Takano Y, Kamata Y, Okayasu J. Bcl-2 expression and allelic loss of the $p 53$ gene in gastric carcinomas. J Cancer Res Clin Oncol 1996;122:427-32.

134. Ayhan A, Yasui W, Yokozaki H, Seto M, Ueda R, Tahara E. Loss of heterozygosity at the $\mathrm{bcl}-2$ gene locus and expression of bcl-2 in human gastric and colorectal carcinomas. Jpn J Cancer Res 1994;85:584-91.

135. Kondo S, Shinomura Y, Kanayama S, Higashimoto Y, Miyagawa JI, Minami T, et al. Over-expression of $b c l-x L$ gene in human gastric adenomas and carcinomas. Int $\mathrm{J}$ Cancer 1996;68:727-30.

136. Yamamoto H, Sawai H, Perucho M. Frameshift somatic mutations in gastrointestinal cancer of the microsatellite mutator phenotype. Cancer Res 1997;57:4420-6.

137. Muller W, Schneiders A, Hommel G, Gabbert HE. Prognostic value of the putative metastasis suppressor gene $n m 23$ in gastric cancer. In: Siewert JR, Roder JD, editors. Progress in gastric cancer research 1997. Bologna: Monduzzi Editore, 1997:7016.

138. Campo E, Miquel R, Jares P, Bosch F, Juan M, Leone A, et al. Prognostic significance of the loss of heterozygosity of Nm23-H1 and p53 genes in human colorectal carcinomas. Cancer 1994; 73:2913-21.

139. Kodera Y, Isobe K, Yamauchi M, Kondoh K, Kimura N, Akiyama S, et al. Expression of nm23 H-1 RNA levels in human gastric cancer tissues. A negative correlation with nodal metastasis. Cancer 1994;73:259-65.

140. Tahara E, Yokozaki H, Yasui W. Molecular prognostic factors of gastric cancer. In: Siewert JR, Roder JD, editors. Progress in gastric cancer research 1997. Bologna: Monduzzi Editore; 1997:371-8.

141. Dorudi S, Sheffield JP, Poulsom R, Northover JM, Hart IR. Ecadherin expression in colorectal cancer. An immunocytochemical and in situ hybridization study. Am J Pathol 1993;142:9816.

142. Yasui W, Akama Y, Kuniyasu H, Yokozaki H, Semba S, Shimamoto F, et al. Expression of cyclin $\mathrm{E}$ in human gastric adenomas and adenocarcinomas: Correlation with proliferative activity and p53 status. J Exp Ther Oncol 1996;1:88-94.

143. Kakeji Y, Korenaga D, Tsujitani S, Haraguchi M, Maehara Y, Sugimachi K. Predictive value of Ki-67 and argyrophilic nucleolar organizer region staining for lymph node metastasis in gastric cancer. Cancer Res 1991;51:3503-6.

144. Lee YY, Kang SH, Seo JY, Jung CW, Lee KU, Choe KJ, et al. Alterations of $p 16 I N K 4 A$ and $p 15 I N K 4 B$ genes in gastric carcinomas. Cancer 1997;80:1889-96.

145. Chen YJ, Chang JG, Shih LS, Chen PH, Endo M, Whang-Peng $\mathrm{J}$, et al. Frequent detection of aberrant RNA transcripts of the $C D K N 2$ gene in human gastric adenocarcinoma. Int J Cancer 1997;71:350-4.

146. Katoh M, Terada M. Oncogenes and tumor suppressor genes. In: Nishi M, Ichikawa H, Nakajima T, Maruyama K, Tahara E, editors. Gastric cancer. Tokyo: Springer-Verlag, 1993:196-208.

147. Kuniyasu H, Yasui W, Kitadai Y, Yokozaki H, Ito H, Tahara E. Frequent amplification of the $c$-met gene in scirrhous type stomach cancer. Biochem Biophys Res Commun 1992;189:227-32.

148. Ishikawa T, Kobayashi M, Mai M, Suzuki T, Ooi A. Amplification of the c-erbB-2 (HER-2/neu) gene in gastric cancer cells. Detection by fluorescence in situ hybridization. Am J Pathol 1997;151:761-8.

149. Sakurai S, Sano T, Maeshima A, Kashiwabara K, Oyama T, Fukuda $\mathrm{T}$, et al. Gastric adenoma-carcinoma sequence with special reference to $p 53$ and Ki-ras gene alterations. Virchows Arch A Pathol Anat Histol 1995;427:119-24.

150. Kim TY, Bang YJ, Kim WS, Kang SH, Lee KU, Choe KJ, et al. Mutation of ras oncogene in gastric adenocarcinoma: Association with histological phenotype. Anticancer Res 1997;17:1335-9.

151. Tahara E, Yokozaki H, Yasui W. Growth factors in gastric cancer. In: Nishi M, Ichikawa H, Nakajima T, Maruyama K, Tahara E, editors. Gastric cancer. Tokyo: Springer-Verlag; 1993:209-17.

152. Chung YJ, Park SW, Song JM, Lee KY, Seo EJ, Choi SW, et al. Evidence of genetic progression in human gastric carcinomas with microsatellite instability. Oncogene 1997;15:1719-26.

153. Souza RF, Lei J, Yin J, Appel R, Zou TT, Zhou X, et al. A transforming growth factor beta 1 receptor type II mutation in ulcerative colitis-associated neoplasms. Gastroenterology 1997;112:40-5.

154. Kern SE, Redston M, Seymour AB, Caldas C, Powell SM, Kornachi S, et al. Molecular genetic profiles of colitis-associated neoplasms. Gastroenterology 1994;107:420-8.

155. Nicolaides NC, Papadopoulos N, Liu B, Wei YF, Carter KC, Ruben SM, et al. Mutations of two PMS homologues in hereditary nonpolyposis colon cancer. Nature 1994;371:75-80.

156. Higashikawa K, Yokozaki H, Ue T, Taniyama K, Ishikawa T, Tarin D, et al. Evaluation of CD44 transcription variants in human digestive tract carcinomas and normal tissues. Int J Cancer 1996;66:11-7.

157. Benhattar J, Saraga E. Molecular genetics of dysplasia in ulcerative colitis. Eur J Cancer 1995;31A:1171-3.

158. Kitahara K, Yasui W, Kuniyasu H, Yokozaki H, Akama Y, Yunotani S, et al. Concurrent amplification of cyclin $E$ and CDK2 genes in colorectal carcinomas. Int J Cancer 1995;62:258.

159. Brentnall TA, Crispin DA, Rabinovitch PS, Haggitt RC, Rubin $\mathrm{CE}$, Stevens AC, et al. Mutations in the p53 gene: An early marker of neoplastic progression in ulcerative colitis. Gastroenterology 1994;107:369-78.

160. Laurén P. Histogenesis of intestinal and diffuse types of gastric carcinoma. Scand J Gastroenterol 1991;26(Suppl 180):160-4.

161. Nevalainen TJ, Jarvi OH. Ultrastructure of intestinal and diffuse type gastric carcinoma. J Pathol 1977;122:129-36. 